\title{
INTEROPERABILITAS IDENTITAS DIGITAL DALAM TRANSAKSI \\ ELEKTRONIK LINTAS NEGARA: SUATU KAJIAN HUKUM \\ TERHADAP SISTEM IDENTIFIKASI DAN AUTENTIKASI \\ ELEKTRONIK MENJELANG ASEAN COMMUNITY 2015
}

\author{
Edmon Makarim ${ }^{1}$
}

\begin{abstract}
Ahead of the the enactment of the ASEAN Community 2015, the question, how far Indonesia ready to commit electronic transactions on a regional basis by optimizing the use of the National e-ID? Through normative research and methods of qualitative data analysis as well as a comparative study, which is based on secondary data (including primary legal materials, secondary and tertiary) and supported by interviewing experts and stakeholders, this study examines and develops the concept of how the legal system can guarantee security and authenticity in access to public services through electronic systems.
\end{abstract}

Keywords: interoperability, electronic transactions, electronic authentication, asean community

\begin{abstract}
Abstrak
Menjelang berlakunya ASEAN Community 2015, menjadi pertanyaan, sejauhmana Indonesia siap melakukan transaksi elektronik secara regional dengan mengoptimalkan pengunaan National e-ID? Melalui penelitian normatif dan metode analisis data kualitatif serta studi komparatif yang bertumpu pada data-data sekunder (mencakup bahan hukum primer, sekunder dan tertier) dan didukung dengan wawancara para ahli dan para pemangku kepentingan, penelitian ini mengkaji dan mengembangkan konsep bagaimana sistem hukum dapat menjamin keamanan dan keautentikan dalam akses pelayanan publik melalui sistem elektronik.
\end{abstract}

Kata kunci: interoperabilitas, transaksi elektronik, autentifikasi elektronik, asean community

\section{Pendahuluan}

Pertanyaan tentang sejauhmana keterpercayaan (trustworthiness) terhadap sistem informasi pemerintah dalam mendukung administrasi

\footnotetext{
${ }^{1}$ Penulis adalah Dosen Inti Penelitian Bidang Hukum Telematika, dan Ketua Lembaga Kajian Hukum Teknologi, Fakultas Hukum Universitas Indonesia. Alamat kontak: edmon_makarim@yahoo.com.
} 
pemerintahan dan pelayanan publik telah menjadi perhatian banyak negara. Seiring terbentuknya Dewan TIK Nasional ("Detiknas") telah dicanangkan 7 (tujuh) program yang salah satunya adalah Nomor Identitas Nasional (single identity number). Implementasinya dilaksanakan dengan UU No.23 Tahun 2006 tentang Administrasi Kependudukan yang terakhir diubah dengan UU No.24 Tahun 2013 ("UU Adminduk") dan juga Peraturan Presiden No.26 Tahun 2009 tentang Penerapan Kartu Tanda Penduduk Berbasis Nomor Induk Kependudukan secara Nasional yang terakhir kali diubah dengan Perpres No.112 Tahun 2013 ("Pepres e-KTP").

Menjelang berlakunya ASEAN Community 2015, menjadi pertanyaan, sejauhmana Indonesia siap melakukan transaksi elektronik secara regional dengan mengoptimalkan pengunaan National e-ID masing-masing negara ASEAN, baik untuk pelayanan publik maupun untuk mendukung regional $e$ commerce. Dalam penelitian RKOI tahap pertama tahun 2013, diperoleh pembelajaran bahwa Amerika Serikat yang bercorak federal masih belum memiliki program National e-ID card, namun mereka tengah menerapkan kebijakan federated identity management melalui penerapan multi credentials. Amerika Serikat mengembangkan kebijakan National Strategic for Trusted Identities in Cyberspace ("NSTIC") dengan model trusted framework guna menciptakan identity ecosystem yang baik dari semua digital identity yang tersedia baik oleh pemerintah (contoh: driving license, social security number) maupun oleh swasta.

Dalam penelitian ini, dilakukan studi perbandingan dengan negara UniEropa. Meskipun beberapa negara anggota Uni Eropa secara nasional menerapkan single credential dengan national $e-I D$ card untuk tujuan multiguna, namun dalam perkembangannya secara regional, mereka juga mengakomodir federated identity management. Guna mengakomodir kebutuhan setiap warga negara dari para negara anggota untuk dapat mengakses pelayanan publik pada negara anggota yang lainnya, maka diperlukan interoperabilitas dalam Uni Eropa. Pada tanggal 28 Agustus 2014 yang lalu, mereka telah mengubah Directive 1999/93/EC tentang Electronic Signature, menjadi Regulation 910/2004 tentang e-Identification and Trust Services for e-transaction in the Internal Market. Dalam waktu dekat, mereka juga akan mengubah Directive 95/46/EC tentang Personal Data Protection menjadi regulasi Uni Eropa, sehingga semua aturan tersebut memiliki keberlakuan yang mengikat kepada setiap negara anggota.

Melalui penelitian normatif dan metode analisis data kualitatif serta studi komparatif yang bertumpu pada data-data sekunder (mencakup bahan hukum primer, sekunder dan tertier) dan didukung dengan wawancara para ahli dan para pemangku kepentingan, penelitian ini mengkaji dan mengembangkan konsep bagaimana sistem hukum dapat menjamin keamanan dan keautentikan dalam akses pelayanan publik melalui sistem elektronik.

Belajar dari Uni Eropa, para negara anggota ASEAN dipandang perlu melakukan hal yang senada untuk menjamin interoperabilitas dari e-ID masing-masing negara guna memfasilitasi e-transaction di ASEAN baik publik maupun privat. Hal tersebut harus didukung dengan harmonisasi perlindungan 
hukum tentang Privacy dan Perlindungan Data Pribadi, cybersecurity, dan penyelenggaraan tanda tangan elektronik yang didukung dengan Government Certification Authority. Indonesia adalah salah satu negara yang harus segera mempersiapkan sistem hukumnya untuk kesiapan AEC 2015 tersebut.

\section{Evolusi Identitas}

Berdasarkan sejarahnya, dilihat dari keberadaan medianya, maka setidaknya dapat dilihat terjadinya evolusi dalam penyajian data suatu identitas, dari penyajian data berbasiskan media kertas menjadi bentuk yang digital yang pada awalnya masih bersifat proprietary dan tersimpan pada media chip (contoh: smart card). Dalam konteks ini keberadaan identitas digital tidak dilepaskan dari keberadaan media penyimpannya sehingga tingkat kepercayaan atas data identittas digital sangat tergantung kepada kepercayaan atau validitas keamanan dalam media penyimpannya itu sendiri. Selanjutnya, sesuai konvergensi telematika, penyajian informasi digital tersebut dikomunikasikan secara elektronik dalam suatu jaringan komunikasi global sehingga berkembanglah penyajian identitas digital menjadi online-identity ${ }^{2}$.

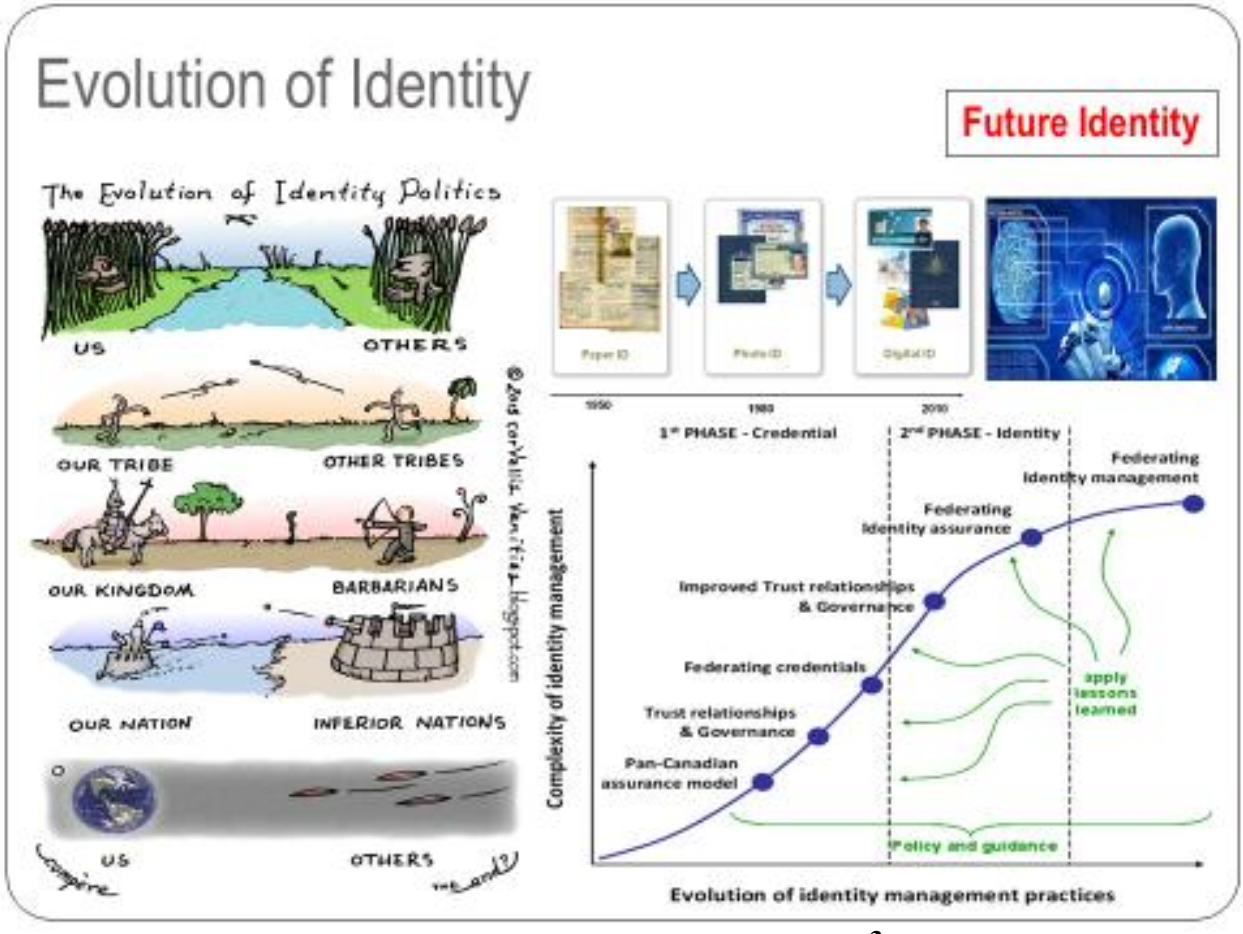

Gambar 2: Evolusi Identitas ${ }^{3}$

${ }^{2}$ Meredith Farkas, American Library Association, In Practice: Brand Perception 2.0, American Libraris, Vol. 41, no. 1/2 (Jan.-Feb., 2010), p. 35), "Online identity is built upon all of the things we have put online and the things people have posted about us."

${ }^{3}$ Dirangkai dari berbagai sumber. 
Menarik untuk dicermati bahwa semula pembicaraan tentang identitas selalu melekat didalamnya pembicaraan tentang media penyimpannya (credentials) contoh KTP, passport, SIM, dan lain sebagainya. Guna mencegah adanya pemalsuan maka umumnya dinamika teknologi yang dikembangkan adalah berkutat kepada upaya untuk mengeliminasi peluang terjadinya pemalsuan tersebut, sehingga berkembanglah system pengamanan dokumen secara kertas (security printing). ${ }^{4}$

Dalam perkembangan berikutnya, selaras dengan dinamika teknologi informasi dan komunikasi, hal itu tidak lagi hanya digantungkan dalam perkembangan media cetak sehingga berkembanglah sistem digital dimana informasi identitas disimpan dan ditampilkan secara digital disertai dengan system pengamanan penggunaan agar informasi tersebut tidak dapat digunakan oleh yang tidak berhak (autorisasi dan autentikasi). Dicermati lebih lanjut, dinamika tersebut seakan telah memilahkan antara keberadaaan isi dengan keberadaan medianya. Dengan kata lain, konten dan media seakan dapat dikatakan sebagai dua hal yang dapat dipisahkan, yakni (i) keberadaan konten data pribadi digital itu sendiri sebagai suatu digital objek (termasuk data biometrics) yang merupakan milik (digital property) dari orang yang bersangkutan (subject data), dan (ii) keberadaan sistem elektronik pengidentifikasian (electronic identification) yang dapat saja merujuk tidak hanya kepada suatu perangkat credential tertentu saja (contoh: kartu chip, baik kontak maupun nir-kontak) melainkan berbagai perangkat yang ada (contoh: computer, USB, handset telephone), berikut penggunaannya melalui jaringan sistem elektronik (network) dengan memastikan adanya otorisasi dan autentikasi dari yang bersangkutan.

Dengan kata lain, juga dapat dikatakan bahwa terlihatk pembedaan antara soft-ID dengan Hard-ID, dimana sangat dimungkinkan keberadaan identitas dengan mekanisme multi-credentials dan lebih bersifat mobile dengankemampuan lintas ssstem teknologi dan organisasi yang berbeda, sehingga berkembanglah pemikiran yang lebih inklusif terhadap keberagaman identitas itu dengan model Federated Identity Management. Hal tersebut telah mendorong pembicaraan mengenai keberadaan mobile identity dan juga cloud computing untuk manajemen identitas guna memfasilitas akses pelayanan public pada e-government maupun untuk kontrak dalam e-commerce. Oleh karena itu, tidaklah mengherankan sekiranya baik di Amerika Serikat maupun di Eropa berkembang pemikiran tentang Identity ecosystem yang membutuhkan suatu kerangka kerja operasional yang jelas untuk menjamin keterpercayaannya (trust framework). Bahkan di Eropa sendiri telah dilakukan penelitian untuk mengakomodir keberadaan identitas masa

\footnotetext{
${ }^{4}$ Salah satu contoh diantaranya adalah menyediakan sesuatu yang keberadaannya hanya dapat dibaca oleh mesin (machine readable zone/MRZ) sebagaimana lazimnya telah diterapkan dalam passport.
} 
depan di tengah masyarakat informasi, Future of Identity in the Information Society (FIDIS).

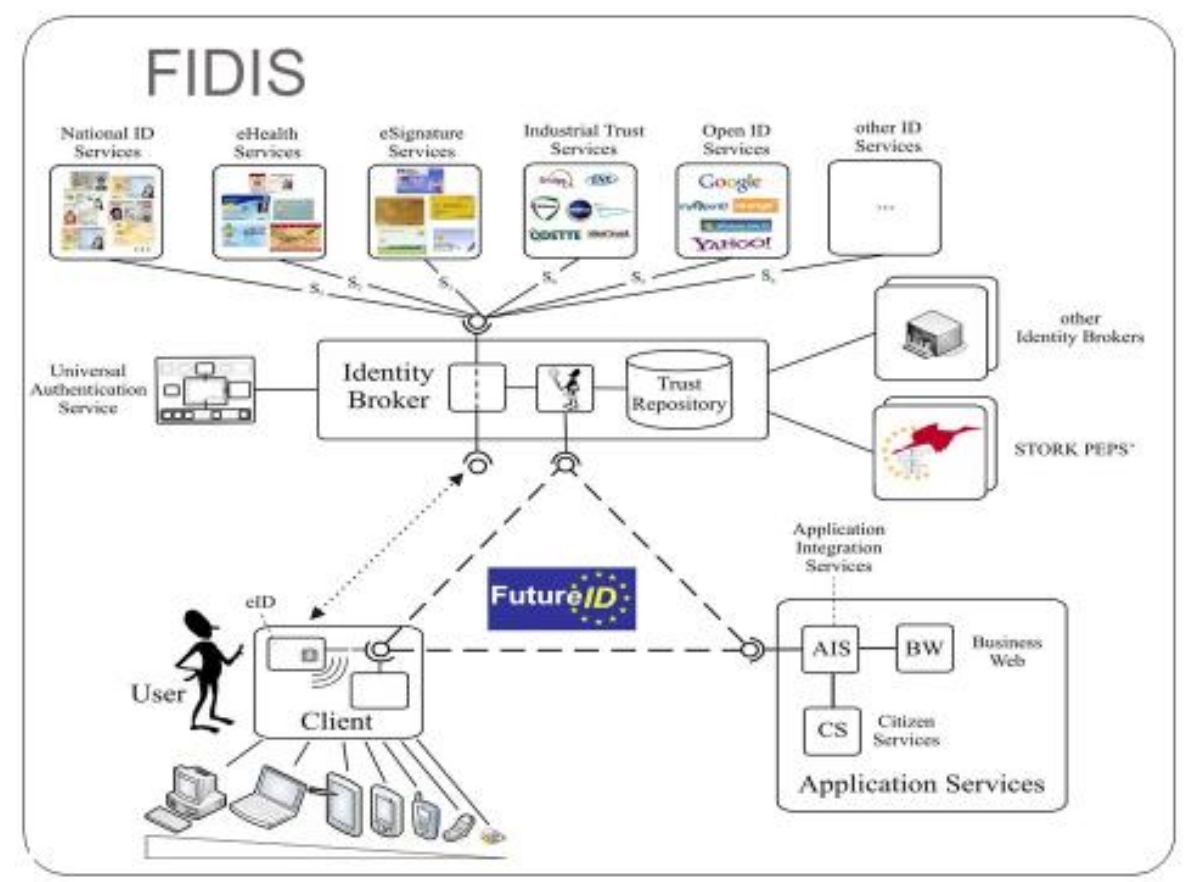

Gambar 3: Future of Identity in the Information Society

Merujuk kepada proses produksinya, setidaknya terdapat dua model pembuatan credential tersebut, yakni: (i) Produksi credential kartu pada saat atau fase personalisasi, dan (ii) produksi credential setelah fase penerbitan kartu. Dalam varian yang pertama, skenario ini relatif cukup sederhana dengan modelstructural yangterpusatsehingga memungkinkan adannya proses autentikan penggunaanpada saat penerbitan kartu. Sementara dalam varian yang kedua, relatif agak sedikit kompleks karena dimungkinkan bahwa warga memperoleh kartunya terlebih dahulu dan proses autentikasinya dilakukan setelah penerbitan kartu. Warga dapat langsung mengunduk sertifikat digital secara online atau melalui outletoutlet resmi baik unit pemerintah maupun swasta (contoh: bank) yang diberikan wewenang dan tanggung jawab untuk itu.

Dalam praktek perkembangannya, federated identity management memungkinkan tumbuhnya berbagai jasa penyedia pembuatan identitas (application service providers) dan cloud computing, baik yang diselenggarakan oleh pemerintah maupun oleh swasta. Hal tersebut juga mendorong tumbuhnya jasa penunjang untuk mendukung keterpercayaan atau keautentikan terhadap identifikasi dan identitas yang diklaim tersebut (trust services provider), seperti antara lain; penyedia tanda tangan elektronik (e-signature provider), cap elektronik (e-seal), stempel waktu (time-stamping), dokumen elektronik (e-document), electronic registered delivery services, dan autentikasi situs laman internet (web-site authentication). 


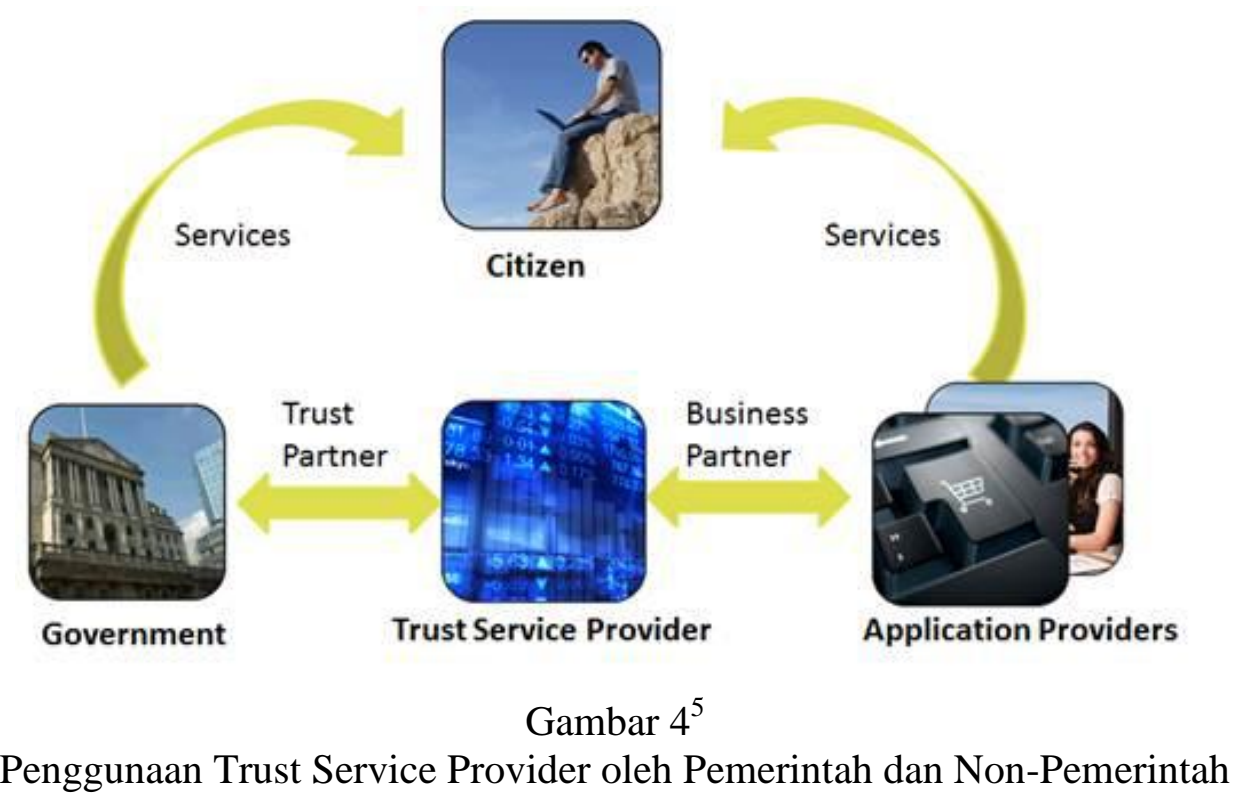

Selanjutnya dengan semakin berkembangnya akses internet via jaringan telekomunikasi bergerak (mobile operator), maka credential tidak lagi hanya pada kartu chip tanda penduduk, melainkan juga dapat menggunakan identitas nomor pada perangkat telepon selular, sekiranya secara sistemik dapat dijamin bahwa pendaftaran identitas pengguna nomor telepon adalah valid. Dengan kata lain, selain data identitas digital yang tertanam pada kartu chip tanda penduduk, juga terdapat kemungkinan tersedianya online identity via mobile yang dapat digunakan untuk askes online public services dan juga online commercial transaction. Penggunaan teknologi tanda tangan digital yang ditunjang dengan penyelenggara Infrastruktur Kunci Publik telah memungkinkan hal itu terjadi.

${ }^{5}$ Dan Butnaru, Smart Card, Mobile Device, Cloud - A natural evolution of electronic ID?, Open Trust. 14/11/2012. 


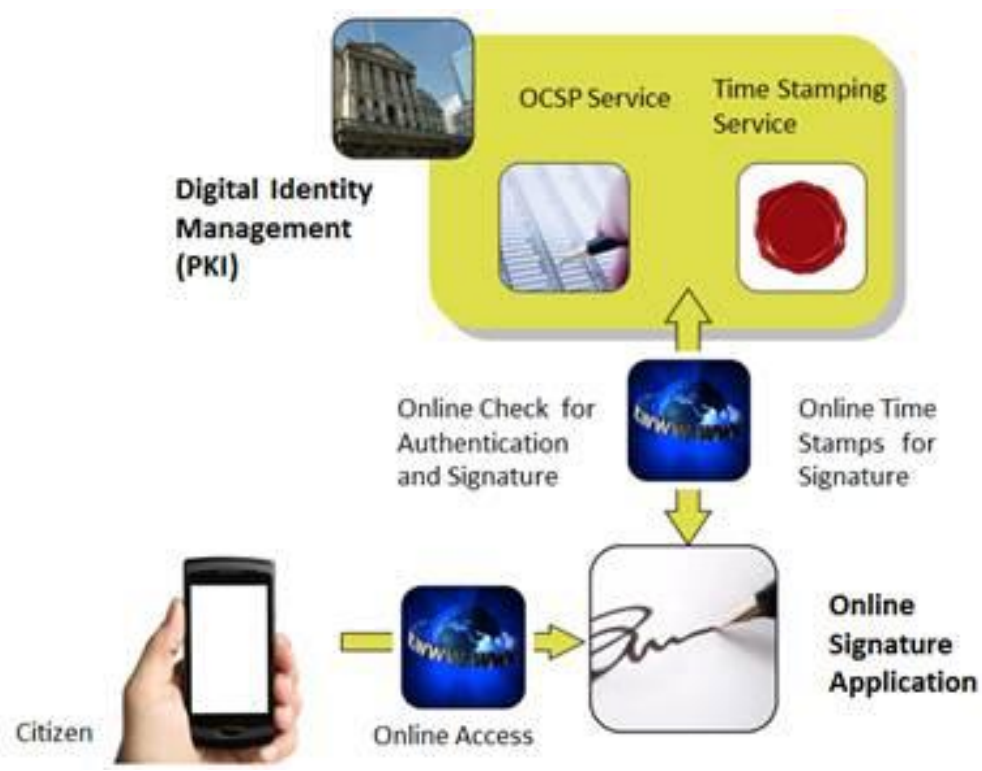

Gambar $5^{6}$

Peranan Infrastruktur Kunci Publik dalam Digital Identity Management

Dari uraian tersebut di atas, dapat dipahami bahwa terdapat suatu kepentingan hukum bagi Negara dan penduduknya, bahwa selain penggunaan credential yang dibuat oleh Negara cq pemerintah untuk mengefisienkan dan mengefektifkan pelayanan dan administrasi pemerintahan, ternyata penduduk juga memerlukan suatu system identitas yang lebih akomodatif untuk berbagai identitas digital yang telah dimilikinya. Hal itu menyiratkan bahwa dalam perkembangannya sekarang ini federated identity management adalah suatu keniscayaan. Dalam prakteknya, baik dalam konteks regional maupun internasional, Negara juga tidak dapat menihilkan keberadaan praktek bisnis yang telah berkembang yang telah ada sebelumnya, oleh karena itu keberadaan national ID card yang mandatory tetap tidak dapat meniadakan keberadaan identitas digital lain yang diberikan oleh swasta maupun komunitasnya.

\section{Keterpercayaan dan Akuntabilitas}

Sebagaimana telah disampaikan pada kerangka konsep dalam bab sebelumnya, dapat disampaikan bahwa terdapat beberapa pengertian tentang keterpercayaan yang pada pokoknya adalah rasa percaya atau kemauan untuk mempercayai (willingnes to belief). Secara umum terdapat kesamaan tentang konsep trustworthiness (keterpercayaan) dalam semua sektor, yakni setidaknya akan berkaitan dengan 3 hal, yaitu percaya walaupun bukti indrawi tidak ada (faith), percaya walaupun

${ }^{6}$ Dan Butnaru, Ibid. 
bukti indrawi belum sempurna (trust), dan percaya karena bukti indrawi dan data telah tersedia (confidence).

Dalam bisnis dan organisasi, trust merupakan faktor yang terpenting yang berfungsi sebagai faktor pengenalan dan pengelolaan risiko. Trust akan sangat berkaitan dengan jaminan keamanan (assurance) yakni jaminan untuk bisa mengelola resiko dengan cara meminimalkan potensi dan mengalihkannya (mitigasi) serta memperjelas pertanggung jawabannya, sehingga bisnis akan berjalan dengan lebih lancar karena menjadi lebih pasti dan lebih baik dalam penanganan resiko tersebut. Sementara dalam hubungan transaksional, trust dapat timbul karena sesuatu kesan atau pengalaman yang baik atau jaminan bahwa sesuatu akan berjalan dengan baik dan dapat dipertanggung jawabkan. Sebagaimana layaknya perikatan, hal tersebut terjadi karena kejelasan subyek para pihak dan kejelasan obyek yang ditransaksikan serta dapat dijadikan bukti adanya transaksi. Dalam prakteknya, meskipun syarat transaksi tersebut tidak terpenuhi, namun seseorang tetap berani melakukan transaksi, jika: (i) tidak adanya pilihan lain (dependability), (ii) percaya atas suatu reputasi pihak lain; (iii) telah melakukan prediksi perhitungan (predictability) bahwa harapan keuntungan akan diperoleh setelah menghitung bahwa potensi resiko kerugian relatif kecil. Hal tersebut dapat terlihat pada transaksi yang bersifat mikro ataupun perjanjian yang bersifat untung-untungan, sebagai contoh adalah pertaruhan dalam suatu permainan.

Doney dan Cannon (1997) mengindentifikasi bahwa Trust in business relationship setidaknya terdapat 5 proses, yakni; (i) Calculative Process, (ii) Prediction Process, (iii) Capability Process, (iv) Intentionality Process, dan (v) Transference Process. Hal tesebut berbeda dengan apa yang disampaikan oleh Rempel (1985) yang pada pokoknya melihat tiga komponen dalam konteks trust in romantic relationsip, yakni; (i) Predictability, (ii) Dependability, dan (iii) Faith. ${ }^{7}$

Secara umum dalam sistem elektronik dikenal tiga kategori trust. (i) Yang pertama adalah trust yang berdasarkan sumber daya eksternal, seperti efek sosial sebagai cara orang bereaksi atas suatu sistem, disini orang menuntut agar sistem dapat dipercaya. (ii) Kedua, pilihan seseorang untuk dapat mempercayai sistem dapat berdasarkan pengetahuan atau pengalaman objektif atas kesuksesan sistem sebelumnya. Hal ini akan menunjukan bahwa sistem dapat diandalkan (reliable and dependable). (iii) Tipe trust yang ketiga merupakan sebuah konsep kombinasi dari dua tipe sebelumnya, dengan menggunakan kesimpulan logis. Trust dapat diperoleh dari proses internal yang menggunakan fakta eksternal.

7 JEJ Prins (ed)., "Trus in Electronic Commerce: The Role of Trust from a Legal and Organizational and a Technical Point of View", (Hague Netherlands: Kluwer Law International, 2002), hal.16-22. 
Dilihat dari prosesnya dapat dibagi menjadi 4 tahapan rentang perolehan keterpercayaan tersebut, yakni dimulai dari (i) proses mengetahui, (ii) proses berinteraksi dengan sistem sehingga memperoleh kesan atau pengalaman terhadap fitur dan fasilitas yang diberikan, (iii) proses pemeriksaan informasi terhadap jaminan validitas isi dan pertanggungjawaban, (iv) sebagai konsekwensinya timbul rasa percaya bahwa sistem tersebut handal, aman dan bertanggung-jawab.

Selanjutnya perlu dicermati tentang karakteristik Networked Information System (NIS) atau sistem elektronik jaringan yang mengintegrasi komputer, sistem komunikasi, prosedur dan orang di dalamnya, baik pengguna maupun operator. Operator sistem elektronik tidak mempunyai kendali atau informasi detail tentang sistem-sistem dalam komponen sistem elektronik, karena tidak mengetahui dengan pasti perangkat lunak apa yang memasuki sistem atau tindakan apa yang komponen itu akan ambil secara otomatis. Pada dasarnya sistem mengenali dan mengidentifikasi semua content dan perangkat melalui identitas digitalnya (digital object identifier). Hal ini tidak secara visual diketahui oleh pengguna melainkan bekerja secara teknis mesin saja.

Ketika seseorang berhadapan dengan sistem elektronik, mereka harus mempelajari cara kerja sistem tersebut. Dalam fase ini, hasil akan dapat diprediksi dan pengguna (user) mulai mempunyai confidence bahwa sistem tersebut akan bekerja sesuai dengan yang diprediksi. Dengan keyakinan tersebut, pengguna akan membangun trust di sistem, lebih mempelajari mengenai tingkah lakunya, keandalannya (reliability) dan risiko menggunakannya. Sebagian besar definisi trust fokus kepada kemungkinan dapat diprediksi (predictability), keandalan (reliability) dan manajemen risiko. Dengan kata lain 'trust' selayaknya hanya dapat diterima sepanjang jika sistem elektronik tersebut akuntabel sehingga dapat diprediksi dan dipercaya kehandalan dan keamanannya serta diketahui sejauhmana pertanggungjawabannya.

Dalam konteks hukum Indonesia, Pasal 15 UU Informasi dan Transaksi Elektronik (UU ITE) ${ }^{8}$ telah memberikan batasan adanya persyaratan untuk memperoleh "Trust" tesebut bahwa suatu Sistem Elektronik harus akuntabel yakni diselenggarakan secara handal, aman dan bertanggung jawab. Pasal 15 UU ITE telah memposisikan 'presumed liablity' bahwa si penyelenggara sistem elektronik harus bertanggung jawab secara hukum kecuali ia dapat membuktikan bahwa kesalahan terjadi bukan karena dirinya melainkan karena kesalahan pengguna atau kejadian alam yang berada diluar pengendaliannya.

Lebih lanjut ketentuan dalam pasal 15 UU ITE diturunkan dalam PP No.82 Tahun 2012 tentang Penyelenggaraan Sistem Elektronik dan Transaksi Elektronik ("PP-PSTE") yang memperhatikan keberadaan setiap komponen dalam sistem elektronik, yang mencakup perangkat dan

\footnotetext{
${ }^{8}$ Undang-Undang Nomor 11 Tahun 2008, Undang-Undang Informasi dan Transaksi Elektronik, (Lembaran Negara No. 58 Tahun 2008, Tambahan Lembaran Negara No. 4843).
} 
prosedur untuk validitas informasi elektronik tersebut agar dapat menjadi bukti hukum yang setara dengan bukti autentik. PP-PSTE memfasilitasi kejelasan subyek penyelenggara dan obyek yang diselenggarakannya dengan kaedah pertama untuk melakukan pendaftaran. Dengan memperhatikan adanya UU Pelayanan Publik, PP-PSTE membebankan kewajiban Sertifikasi Kelaikan bagi sistem elektronik yang digunakan untuk transaksi pelayanan publik. Sementara, Sertifikasi Kehandalan bagi sistem elektronik yang non pelayanan publik adalah bersifat fakultatif, dimana semangatnya adalah penerapan akreditasi secara sukarela (voluntary accreditation).

Berdasarkan paparan tersebut di atas maka ukuran adanya "trust in esystem" di Indonesia adalah setiap penyelenggara telah memenuhi persyaratan yang telah ditentukan dalam UU-ITE dan PP-PSTE.

\section{Dinamika Internasional tentang National e-ID Management dan Sistem Keautentikan}

Berdasarkan hasil penelusuran, setidaknya terdapat dua hasil penelitian secara internasional dari 2 (dua) Organisasi Internasional yang dapat dijadikan rujukan penting dalam penelitian ini, yakni hasil penelitian dari: 1) United Nations Commission on International Trade Law (UNCITRAL)dan2) Organization for Economic Cooperation and Development (OECD). Sesuai hasil penelitiannya, UNCITRAL menguraikan tentang Promoting Confidence in e-Commerce: Legal Issues on International Use of Electronic Authentication and Signature Methods ${ }^{9}$ dan pembahasan tentang manajemen identitas dalam rapat Working Group IV (Electronic Commerce) Forty-sixth session di Vienna 2012; sementara OECD menguraikan tentang (i) Digital Identity Management: enabling innovation and trust in the internet economy; dan (ii) National Strategies and Policies for Digital Identity Management in OECD Countries ${ }^{10}$.

\section{UNCITRAL}

Pada tahun 2009, UNCITRAL telah melakukan penelitian yang inti temuannya adalah bahwa $e$-authentication adalah ekuivalen dengan $e$ signatures. Keautentikan secara elektronik dalam prakteknya di implementasikan dalam bentuk penyelenggraan sistem tanda tangan

\footnotetext{
${ }^{9}$ United Nations Commision on International Trade Law, Promoting Confidence in eCommerce: Legal Issues on International Use of Electronic Authentication and Signature Methods, Vienna, 2009. "Overview of methods used for electronic signature and authentication and their legal treatment in various jurisdictions and the use of lectronic signature and authentication methods in international transactions and identifies the main legal issues related to cross-border recognition of such methods."

10 Organisation for Economic Co-operation and Development, "Digital Identity Management: Enabling Innovation and Trust in the Internet Economy”, 2011.
} 
elektronik. Meskipun terdapat beberapa kebijakan yang berbeda antara negara dalam penyelenggaraan e-authentication ataupun e-signatures tersebut, yang membagi nilai kekuatan pembuktian dan keterpercayaan terhadap sistem, namun demi interoperabilitas transaksi perdagangan global maka tingkatan e-authentication selayaknya tidak terlalu tinggi antara negara.

Dalam bagian pertama hasil penelitian tersebut, UNCITRAL memperhatikan bahwa nilai pembuktian berbanding lurus dengan metode $e$-authentication atau e-signatures yang dipilih dan merepresentasikan asusmsi umum siapa yang bertanggung jawab terhadap suatu dokumen elektronik (general attribution of e-records). Demi interoperabilitas perdagangan secara internasional, UNCITRAL mendorong penerapannya secara international yang selaras dengan model electronic appostilles, sedangkan penerapan nasional domestik dengan model electronic notary ataupun cybernotary. Sedangkan dalam bagian kedua dari hasil penelitian tersebut mendorong adanya pengakuan hukum dari setiap negara terhadap e-authentication dari negara lain (legal recognition of foreign eauthentication and signature methods), dengan kriteria kepada rujukan tempat negara asal (place of origin), prinsip resiprositas dan validasi lokal (local validation), serta penyetaraan substantif (substantive equvalence). Hal tersebut dapat terfasilitasi baik secara hukum maupun secara elektronik, dengan kejelasan kebijakan dan aturan dalam pertanggungjawaban terhadap penyelenggaraan tanda tangan elektronik yang menggunakan tanda tangan digital (digital signatures) yang didukung dengan sertifikasi elektronik (digital certificates) yang berinduk (root) dan berbasiskan Public Key Infrastructure ("PKI").

Perlu dicatat bahwa setidaknya terdapat dua jenis model penyelenggaraan, yakni (i) yang berinduk atau bermuara kepada PKI pemerintah (Government PKI dengan mekanisme National Root CA) maupun (ii) yang berinduk pada masing-masing root secara privat (Private Root $C A$ ) dan kemudian dijembatani oleh CA pemerintah (Bridge CA). ${ }^{11}$ Dalam konteks Indonesia, sesuai Peraturan Pemerintah Republik Indonesia Nomor 82 Tahun 2012 tentang Penyelenggaraan Sistem dan Transaksi Elektronik, ${ }^{12}$ kedua hal tersebut dapat diakomodir, dimana Kementerian Komunikasi dan Informasi adalah penyelenggara CA pemerintah (Government $C A$ ) sedangkan National $C A$ ataupun Bridge $C A$ masih belum ditentukan.

${ }^{11}$ Root CA berbeda dengan Bridge CA. Root CA akan melakukan sertifikasi terhadap sertifikat elektronik dibawahnya, sementara Bridge CA hanya bertindak sebagaimana layaknya 'hub' sehingga hanya melakukan sertifikasi terhadap Root CA tetapi tidak mensertifikasi keberadaan sertifikat dibawahnya.

${ }^{12}$ Peraturan Pemerintah Republik Indonesia No. 82 Tahun 2012, Peraturan Pemerintah tentang Penyelenggaraan Sistem dan Transaksi Elektronik, (Lembaran Negara Republik Indonesia No. 189 Tahun 2012, Tambahan Lembaran Negara No. 5348). 
Selanjutnya pada tahun 2013, dalam forum UNCITRAL, delegasi Amerika Serikat mengingatkan pentingnya kejelasan tentang identitas subyek hukum dalam mendukung global e-commerce. Hal itu sesungguhnya menjadi kunci atau persyaratan mendasar dalam kesuksesan pembicaraan selanjutnya khususnya terkait electronic signatures, single windows, electronic transferable records dan juga mobile payment system.

Verification of identity is also a critical requirement for electronic transferable records, single window, and mobile payments. Current law regarding electronic transferable records requires establishing the identity of both the signer of the record as well as the holder entitled to enforce it. Single window processes will require establishing the identity of the signer of customs documents, as well as the identity of the person or entity filing them and the person or entity entitled to enforce them. And mobile payments, like all other payment systems, require (for purposes of authorization) the identity of the person purporting to transfer funds.

Lebih lanjut, mereka mengemukakan bahwa terdapat hambatan permasalahan hukum yang selayaknya menjadi perhatian bersama antar Negara, yakni:

1) Law not written to address identity management, ${ }^{13}$

2) Legal uncertainty/ambiguity; ${ }^{14}$

3) Privacy issues, ${ }^{15}$

${ }^{13}$ UNCITRAL, Ibid. [Many novel issues raised by identity management processes are simply not addressed by existing law. Most existing laws that apply in these contexts were not written from the perspective of digital identity systems, and thus often inadequately or inappropriately address or regulate identity activities. For example, existing law is typically silent with regard to the duty of care an identity proofer must meet when evaluating the authenticity of identity proofing documents, or the scope of any disclosure duty owed by an identity provider to a data subject];

${ }^{14}$ UNCITRAL, Ibid. [There are some identity management issues that existing laws and regulations may address, but the applicability of those laws is often unclear or ambiguous, leaving identity system participants with a great deal of legal uncertainty that can retard growth, innovation and investment. Thus, even where existing law applies to identity management, the manner in which it will apply to a specific issue or proposed approach in an identity system may not be clear. This is particularly true with respect to laws focused on a specific technology. This may limit the ability of parties entering into identity transactions to assess and manage the risks they assume by so doing];

15 UNCITRAL, Ibid. [This may involve addressing questions such as: (i) What information may be collected by the identity provider?; (ii) How much information may be disclosed to relying parties?; (iii) What control does the subject have regarding disclosure?; (iv) How securely must the data be handled by the parties?; and (v) What limits are imposed on use of the information by the identity provider and relying parties? These questions are often addressed by existing laws, which may also be supplemented by contract-based operating rules]; 
4) Liability issues: ${ }^{16}$

5) Jurisdictional variations and conflicts, ${ }^{17}$

6) Need for legal interoperability; ${ }^{18}$

7) Restrictions on ability to modify law by contract. ${ }^{19}$

Dari beberapa hal yang disampaikan oleh delegasi Amerika Serikat tersebut, maka jelas terlihat bahwa demi mendukung terjadinya global ecommerce yang baik, maka sebaiknya setiap Negara perlu melakukan pengembangan sistem hukum nasional tentang kejelasan sistem identitas digital nasionalnya, baik yang diselenggarakan oleh pemerintah maupun oleh Swasta. Setidaknya diperlukan suatu kerangka kerja hukum sebagai 'operating rules' ataupun 'trust framework' dalam pengelolaan identitas digital yang bersifat terbuka interoperabiitasnya dengan berbagai identitas digital yang lain (federated identity system).

${ }^{16}$ UNCITRAL, Ibid. [A legal concern of primary importance to the participants in any identity system is determining who will bear liability associated with any of the risks (see para. 24 above). Numerous statutory, common law, and contract theories have been advanced to identify, define, and clarify the source and scope of such potential liabilities.46 Yet, these legal risks are often ill-defined and uncertain. The concerns around liability represent a key barrier to private sector adoption of interoperable identity solutions. Addressing liability issues by operating rules or other forms of contractual agreement among the participants is often the best approach, particularly because this permits the contract "customization" needed to address the appropriate risk allocation that will vary from case-to-case];

${ }^{17}$ UNCITRAL, Ibid. [There are some key issues on which the application of existing laws and regulations to identity activities varies considerably across jurisdictions. This is often the case with respect to laws governing participant liability and data protection laws governing the privacy of personal information. Moreover, in some cases, regulation or licensing of identity system activities may pose additional barriers to the cross-border operation of identity systems. Thus, when identity systems operate across jurisdictional borders, the challenges of developing appropriate operating rules are compounded by the fact that existing laws and regulations vary (often significantly) between jurisdictions];

${ }^{18}$ Identity systems are challenged by the fact that applicable laws may differ from jurisdiction to jurisdiction. In the absence of uniform laws governing their activities, identity systems often seek to address this problem by developing operating rules that provide legal interoperability to the overall system. The variation of laws and regulations among jurisdictions will challenge construction of such operating rules and other contracts that are needed to render system participant performance more uniform across online systems;

${ }^{19}$ Some existing laws and regulations can be modified by contract. For example, many statutes incorporate doctrines of contract or commercial law that merely establish "default rules" which apply in the absence of express choice by the parties, but permit modification of those rules by agreement of the parties to a transaction. In such cases, parties to an identity system are free to modify default rules and fill-in the blanks by the use of appropriate contractbased operating rules. In other cases, however, mandatory rules of law cannot be disregarded by mere agreement of the parties, because they serve public policy purposes such as the protection of consumers or third parties 
To develop a federated identity system requires a combination of technical standards and systems, business processes and procedures, and legal rules that, taken together, establish a trustworthy system for: (i) verifying identity and connecting that identity to an individual human, legal entity, device, or digital object, (ii) providing that identity information to a party that requires it to authorize a transaction, and (iii) maintaining and protecting that information over its life cycle. Critical to making it work in a commercial context is the requirement for an appropriate, and typically contract-based legal framework that defines the rights and responsibilities of the parties, allocates risk, and provides a basis for enforcement. This legal framework is often referred to as "operating rules" or a "trust framework. $^{20}$

\section{OECD}

Pada sekitar tahun 2009-2010, OECD telah mensurvey beberapa Negara anggotanya tentang penerapan digital identity management dengan setidaknya melihat kepada beberapa kebijakan yang diperlukan, yakni (i) kebijakan bagaimanan melakukan registrasi; (ii) kebijakan tentang penggunaan credential; (iii) kebijakan untuk melakukan interoperabilitas; (iv) kebijakan tentang pengamanan informasi dan komunikasi; (v) kebijakan tentang perlindungan privasi dan data pribadi; dan (vi) kebijakan tentang pemberdayaan dan kesadaran pengguna.

Berdasarkan hasil penelitian tersebut, pada dasarnya OECD menguraikan adanya 4 (empat) model kebijakan dalam pengelolaan digital ID, yakni yang bersifat (i) Silo, (ii) Centralized, (iii) Federated, dan (iv) User Centric. OECD memberikan tabel komparasi manfaat dan kekurangan dari beberapa model tersebut sebagai berikut:

\footnotetext{
${ }^{20}$ UNCITRAL, Ibid.
} 
Tabel 2

Perbandingan Kebijakan Digital Identity

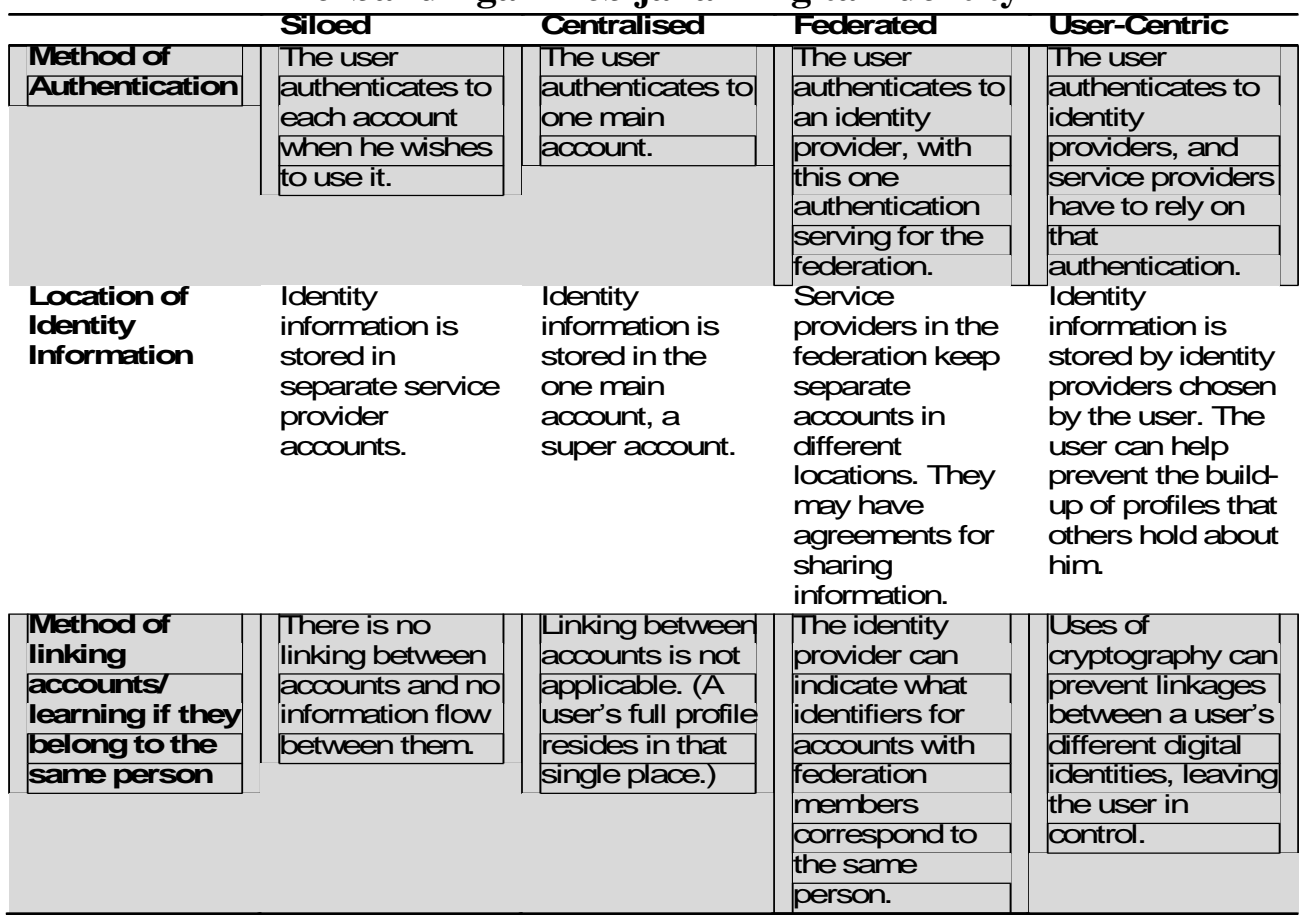

Tabel 3

Perbandingan Kebijakan Digital Identity

\begin{tabular}{|c|c|c|c|c|}
\hline & Siloed & Centralised & Federated & User-Centric \\
\hline $\begin{array}{l}\text { Trust } \\
\text { Characteristics } \\
\text { (who is } \\
\text { clependent on } \\
\text { whom, for } \\
\text { what) }\end{array}$ & $\begin{array}{l}\text { The user is } \\
\text { reliant on the } \\
\text { senvice provider } \\
\text { to protect their } \\
\text { information, } \\
\text { even if limited. } \\
\text { The absence of } \\
\text { information } \\
\text { sharing has } \\
\text { privacy } \\
\text { advantages. }\end{array}$ & $\begin{array}{l}\text { The user is } \\
\text { reliant on the } \\
\text { service provider } \\
\text { to maintain the } \\
\text { privacy and } \\
\text { security of all of } \\
\text { his or her data. }\end{array}$ & $\begin{array}{l}\text { Users have } \\
\text { rights from } \\
\text { contracts, but } \\
\text { they may be } \\
\text { unfamiliar with } \\
\text { options. The } \\
\text { federation has } \\
\text { leverage as it is } \\
\text { in possession of } \\
\text { the user's } \\
\text { information. }\end{array}$ & $\begin{array}{l}\text { Users can keep } \\
\text { accounts } \\
\text { separate and still } \\
\text { allow information } \\
\text { to flow, but bear } \\
\text { greater } \\
\text { responsibility. }\end{array}$ \\
\hline Convenience & $\begin{array}{l}\text { Siloed accounts } \\
\text { are inconvenient } \\
\text { for users and } \\
\text { service } \\
\text { providers due to } \\
\text { multiple } \\
\text { authentications, } \\
\text { redundant entry } \\
\text { of information, } \\
\text { andlack of data } \\
\text { flow. } \\
\end{array}$ & 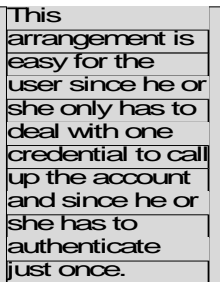 & \begin{tabular}{|l|} 
Other members \\
Of the federation \\
avoid the \\
burden of \\
credential \\
management. \\
Organisations \\
that provide \\
services to a \\
user can \\
coordinate \\
service delivery. \\
\end{tabular} & 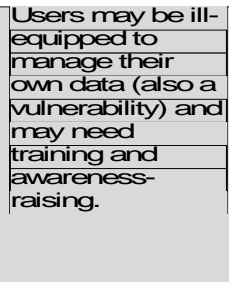 \\
\hline Vulnerabilities & $\begin{array}{l}\text { Sloed systems } \\
\text { offer the } \\
\text { advantage of } \\
\text { having limited } \\
\text { data on hand, } \\
\text { thus creating } \\
\text { less of an } \\
\text { incentive for } \\
\text { attack. They } \\
\text { also have a } \\
\text { better defined } \\
\text { and stronger } \\
\text { security } \\
\text { boundary to keep } \\
\text { attackers out and } \\
\text { limit exposure } \\
\text { from failures. }\end{array}$ & $\begin{array}{l}\text { The central } \\
\text { party controls } \\
\text { the person's } \\
\text { entire profile; } \\
\text { other entities } \\
\text { have little to } \\
\text { check that } \\
\text { profile against, } \\
\text { and an insider } \\
\text { could } \\
\text { impersonate the } \\
\text { person or alter } \\
\text { data. Ourrently } \\
\text { there is no way } \\
\text { to safeguard } \\
\text { data after it has } \\
\text { been shared. }\end{array}$ & $\begin{array}{l}\text { Users have little } \\
\text { input into the } \\
\text { business-partner } \\
\text { agreements. } \\
\text { Some service } \\
\text { providers will set } \\
\text { up federation } \\
\text { systems to } \\
\text { exploit users. } \\
\text { Currently there } \\
\text { is no way to } \\
\text { safeguard data } \\
\text { after it has been } \\
\text { shared. }\end{array}$ & $\begin{array}{l}\text { Concentration in } \\
\text { the market for } \\
\text { identity providers } \\
\text { could leave them } \\
\text { with much power. } \\
\text { Currently there is } \\
\text { no way to } \\
\text { safeguard data } \\
\text { after it has been } \\
\text { shared. }\end{array}$ \\
\hline
\end{tabular}




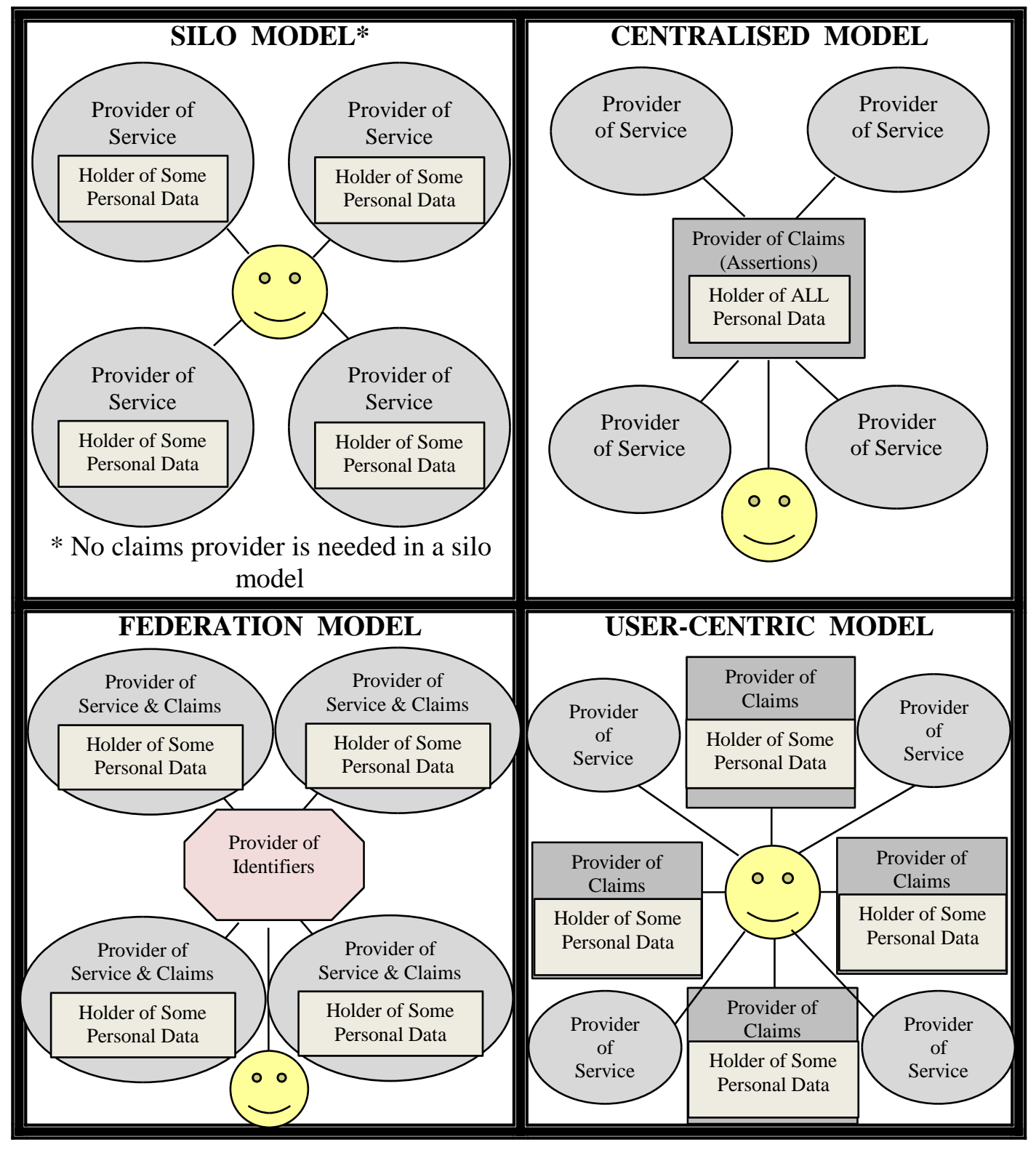

Gambar 6

Diagram Model Kebijakan Digital Identity

Berdasarkan hasil riset tersebut di atas, OECD memberikan beberapa catatan yang dapat digunakan oleh Negara-negara yang ingin menerapkan kebijakan identitas digital nasionalnya dengan baik, setidaknya harus memperhatikan 5 hal, yakni; (i) proses registrasi; (ii) proses otorisasi; (iii) proses autentikasi; (iv) mekanisme akses control yang patut; dan (v) proses revokasi/penarikan yang baik.

1) In order to be known by the system, the individual must first register with it and the conditions related to his/her identity or identity attributes must be checked so he/she can be provided with a set of 
credentials; this is the so-called registration or enrolment process.

2) Appropriate permissions and privileges to access the organisation's resources must be assigned to the individual, a process often called authorization.

3) To access resources, the individual makes an identity claim that can be verified: he/she logs into the system with the credentials provided during the registration process. This authentication process establishes confidence in the user's identity.

4) The result of the authentication process is used in a process called access control, whereby the system checks that the individual has the appropriate authorisation to access the resource.

5) When the individual is not associated anymore with the system, a revocation process must take place whereby his/her credentials are rescinded.

Penting dicatat bahwa OECD juga memperhatikan perkembangan di Eropa, khususnya beberapa Negara Uni Eropa (contoh: Belanda, dll). Sebagai suatu negara dibawah kesepakatan regional Eropa, pada dasarnya Belanda juga harus memperhatikan sinkronisasi kebijakan dan regulasi dengan komunitas Eropa. Sekilas tampak bahwa adanya harmonisasi kebijakan national dan regional untuk identitas masyarakat negara eropa. Dalam perkembangan terakhir, Eropa tengah melakukan perbaikan hukum untuk perlindungan data pribadinya dengan memasukkan hak baru yakni Right to be Forgotten, dan memperbaiki Directive tentang $e$-signatures dengan penambahan ketentuan tentang $e$ identification and trust services.

Electronic identification (eID) and electronic trust services (eTS - namely electronic signatures, electronic seals, time stamp, electronic delivery service and website authentication) are inseparable by essence when analysing the requirements needed to ensure legal certainty, trust and security in electronic transactions.

In this regard, the draft regulation proposes to:

- ensure that people and businesses can use their own national electronic identification schemes (eIDs) to access public services in other EU countries where eIDs are available.

- create an European internal market for eTS by ensuring that they will work across borders and have the same legal status as traditional paper based processes. Only by providing certainty on the legal validity of all these services, businesses and citizens will use the digital interactions as their natural way of interaction.

eID and eTS, both elements of the Regulation, will create a predictable regulatory environment to enable secure and seamless electronic interactions between businesses, citizens and public authorities. This will increase the effectiveness of public and private online services, eBusiness and electronic commerce in the EU.

An Action Plan on eSignatures and eIdentification has been adopted in 2008, with the aim to remove interoperability barriers. 


\section{Perkembangan Proyek KTP-el Tahun 2014}

Isu perkembangan proyek KTP-el pada tahun 2014 ini diantaranya berhubungan dengan beberapa hal, yakni keberlakuan efektif KTP-el dan pengadaannya, penyimpangan-penyimpangan dalam pelaksanaan KTP-el, serta perkembangan penggunaan KTP-el untuk pelayanan publik dan pemilihan umum. Beberapa point penting dari lahirnya UU No. 24 tahun 2013 yang merevisi UU No.23 tahun 2006 tentang Administrasi Kependudukan adalah sebagai berikut: ${ }^{21}$

1. Masa Berlaku KTP Elektronik (KTP-el) yang berlaku untuk seumur hidup;

2. Penggunaan Data Kependudukan Kementerian Dalam Negeri ${ }^{22}$

3. Pencetakan Dokumen/Personalisasi KTP-el

4. Penerbitan Akta Kelahiran yang Pelaporannya melebihi Batas Waktu 1 (satu) Tahun;

5. Penerbitan Akta Pencatatan Sipil yang semula dilaksanakan di tempat terjadinya Peristiwa Penting, diubah menjadi penerbitannya di tempat domisili penduduk;

6. Pengakuan dan Pengesahan Anak; ${ }^{23}$

7. Pengurusan dan Penerbitan Dokumen Kependudukan Tidak Dipungut Biaya (Gratis); ${ }^{24}$

8. Pencatatan Kematian; ${ }^{25}$

9. Stelsel Aktif, yang semula aktif diwajibkan kepada penduduk, diubah menjadi stelsel aktif diwajibkan kepada pemerintah melalui petugas;

${ }^{21}$ Diringkaskan dari situs resmi kementrian dalam negeri RI.

22 Data Kependudukan Kementerian Dalam Negeri yang bersumber dari data kependudukan kabupaten/kota, merupakan satu-satunya data kependudukan yang digunakan untuk semua keperluan: alokasi anggaran (termasuk untuk perhitungan DAU), pelayanan publik, perencanaan pembangunan, pembangunan demokrasi, penegakan hukum, dan pencegahan kriminal (pasal58UU No. 24 Tahun 2013).

${ }^{23}$ Dibatasi hanya untuk anak yang dilahirkan dari perkawinan yang telah sah menurut hukum agama tetapi belum sah menurut hukum negara (pasal 49 ayat 2). Pengesahan anak yang selama ini hanya dengan catatan pinggir diubah menjadi Akta Pengesahan Anak (pasal 49 ayat 3 UU No. 24 Tahun 2013).

${ }^{24}$ Larangan untuk tidak dipungut biaya semula hanya untuk penerbitan KTP-el, diubah menjadi untuk semua dokumen kependudukan seperti KK, KTP-el, Akta Kelahiran, Akta Perkawinan, Akta Kematian, Akta Perceraian, Akta Pengakuan Anak, dan lain-lain (pasal 79A UU No. 24 Tahun 2013).

${ }^{25}$ Pelaporan pencatatan kematian yang semula menjadi kewajiban penduduk, diubah menjadi kewajiban RT atau nama lain untuk melaporkan setiap kematian warganya kepada Instansi Pelaksana (pasal 44 ayat 1 UU No. 24 Tahun 2013). Pelaporan tersebut dilakukan secara berjenjang melalui RW atau nama lain, Desa/Kelurahan dan Kecamatan. Dengan kebijakan ini diharapkan cakupan pencatatan kematian akan meningkat secara signifikan. 
10. Petugas Registrasi;

11. Pengangkatan Pejabat Struktural pada Unit Kerja Administrasi Kependudukan;

12. Pendanaan Program dan Kegiatan Adminduk dibebankan pada APBN;

13. Penambahan Sanksi:

a. Setiap orang yang memerintahkan dan/atau memfasilitasi dan/atau melakukan manipulasi data kependudukan dan/atau elemen data penduduk dipidana dengan pidana penjara paling lama 6 (enam) tahun dan/atau denda paling banyak Rp. 75.000.000 (pasal 94 UU No. 24 Tahun 2013);

b. Setiap pejabat dan petugas pada Desa/Kelurahan, Kecamatan, UPTD, Instansi Pelaksana yang memerintahkan dan/atau memfasilitasi pungutan biaya kepada penduduk dalam pengurusan dan penerbitan dokumen kependudukan dipidana dengan pidana penjara paling lama 6 (enam) tahun dan/atau denda paling banyak Rp. 75.000 .000 (pasal 95B UU No. 24 Tahun 2013);

c. Setiap orang atau Badan Hukum yang tanpa hak mencetak, menerbitkan, dan/atau mendistribusikan dokumen kependudukan dipidana dengan pidana penjara paling lama 10 (sepuluh) tahun dan/atau denda paling banyak Rp. 1.000.000.000 (pasal 95B UU No. 24 Tahun 2013).

Sehubungan dengan perlindungan data pribadi, terjadi kekhawatiran terhadap kategori sensitifitas data dan batasan perlindungan kerahasiaan data pribadi yang tidak lagi melihat bio-data, sebelumnya akibat perumusan dalam Pasal 84, yakni:

(1) Data Pribadi Penduduk yang harus dilindungi memuat:

a. keterangan tentang cacat fisik dan/atau mental;

b. sidik jari;

c. Iris mata;

d. tanda tangan; dan

e. elemen data lainnya yang merupakan aib seseorang.

(2) Ketentuan lebih lanjut mengenai elemen data lainnya yang merupakan aib seseorang sebagaimana dimaksud pada ayat (1) huruf e diatur dalam Peraturan Pemerintah.

\section{Keberlakuan KTP-el dan Pengadaannya}

Berdasarkan Peraturan Presiden Nomor 126 Tahun 2012 tentang Perubahan Ketiga Atas Peraturan Presiden Nomor 26 Tahun 2009 tentang Penerapan Kartu Tanda Penduduk Berbasis Nomor Induk Kependudukan Secara Nasional, KTP non elektronik berlaku paling lambat tanggal 31 Desember 2013. Hal ini berarti bahwa mulai 1 Januari 2014, diharapkan seluruh penduduk telah menggunakan KTP elektronik (KTP-el) sehingga KTP-el dapat berlaku secara efektif. Namun, 
efektivitas keberlakuan KTP-el tersebut kembali diundur. Berdasarkan Peraturan Presiden Nomor 112 Tahun 2013, KTP non elektronik tetap berlaku bagi para penduduk yang belum memperoleh KTP-el paling lambat hingga tanggal 31 Desember 2014. Menurut Kementerian Dalam Negeri, pengunduran ini terjadi dikarenakan masih adanya sejumlah kendala dalam proses distribusi KTP-el, dan masih banyaknya warga yang belum melakukan perekaman data. ${ }^{26}$

Sebagai contoh, di Kabupaten Labuhanbatu, Provinsi Sumatera Utara, sebanyak 119.357 warga dari 345.421 wajib KTP yang tersebar di 9 (sembilan) kecamatan belum melakukan perekaman data untuk KTP-el. Hal ini berdasarkan data per tanggal 15 April 2014. Kemudian, dari sekitar 226.064 warga yang telah melakukan perekaman data, baru sekitar 223.095 lembar KTP-el yang telah dicetak, dan sekitar 2.969 belum dicetak. ${ }^{27}$ Kemudian, di Kabupaten Gianyar, Bali, distribusi KTPel yang sudah tercetak di instansi pusat mengalami keterlambatan. Kemudian, untuk KTP-el yang sudah terdistribusi pun juga mengalami kendala salah hasil cetak nama atau identitas, dan untuk memperbaikinya harus dibawa ke instansi pusat lagi. Untuk mengantisipasi kebutuhan KTP, pemerintah Kabupaten Gianyar terpaksa mencetak KTP nonelektronik meskipun dalam jumlah terbatas. ${ }^{28}$ Di wilayah Jakarta sendiri, contohnya di Kalideres, Jakarta Barat, sekitar 30 persen dari warga belum memiliki KTP-el, dan hingga kini masih banyak warga yang membuat KTP-el di kantor kelurahan Kalideres tersebut. ${ }^{29}$ Kemudian di wilayah Bogor, sekitar 200.000 warga belum memiliki KTP-el akibat berbagai kendala diantaranya, masih ada warga yang belum melakukan perekaman data, dan warga yang belum memperoleh KTP-el yang sudah dicetak karena kurangnya blanko dari pusat. ${ }^{30}$

26 Hendy Salim, Evaluasi Implementasi e-KTP di Indonesia, Universitas Bina Nusantara, <http://sisteminformasi.blog.binusian.org/2014/04/12/evaluasi-implementasi-e-ktpdi-indonesia/>, diakses pada tanggal 12 April 2014.

27 Sartana Nasution, 19.357 Warga Belum Terekam e-KTP, Sindonews.com, <http://daerah.sindonews.com/read/874106/24/19-357-warga-belum-terekam-e-ktp>, diakses pada tanggal 17 Juni 2014.

${ }^{28}$ Agung Dharmada, Distribusi E-KTP Ngadat, Capil Masih Berlakukan KTP SIAK, Balipost, <http://balipost.com/read/headline/2014/04/30/10811/distribusi-e-ktp-ngadat-capilmasih-berlakukan-ktp-siak.html>, diakses pada tanggal 30 April 2014.

${ }^{29}$ Pembuatan e-KTP di Kelurahan Kalideres Masih Berjalan dan Ternyata 30 Persen Warga Kalideres Tak Punya e-KTP, <http://wartakota.tribunnews.com/2014/04/24/pembuatane-ktp-di-kelurahan-kalideres-masih-berjalan> dan <http://wartakota.tribunnews.com/2014/04/ 24/ternyata-30-persen-warga-kalideres-tak-punya-e-ktp>, diakses pada tanggal 30 April 2014.

30 Ratusan Ribu Warga Bogor Belum Memiliki E-KTP, <http://wartakota. tribunnews.com/2014/04/25/ratusan-ribu-warga-bogor-belum-memiliki-e-ktp>, diakses pada tanggal 25 April 2014.. 
Menurut Kepala Dinas Kependudukan dan Catatan Sipil DKI Jakarta, Purba Hutapea, carut-marutnya pengadaan KTP-el dikarenakan Kementerian Dalam Negeri tidak memiliki Standar Operasional Prosedur (SOP) untuk lama waktu tunggu KTP-el mulai dari perekaman data hingga akhirnya sampai ke tangan warga. Pengecekan akan identitas ganda dilakukan oleh Kementerian Dalam Negeri, sementara tugas instansi daerah hanya melaksanakan perekaman data, oleh karena itu dibutuhkan SOP agar warga dapat mengetahui berapa lama mereka harus menunggu keabsahan identitas mereka, apakah ganda atau tidak, sehingga KTP-el dapat dicetak. Purba Hutapea mengatakan bahwa masih ada sekitar 350.000 warga Jakarta yang sudah melakukan perekaman data sejak tahun 2011, namun hingga tahun 2014 belum mengetahui apakah data yang mereka rekam itu sah atau tidak. ${ }^{31}$

Proyek KTP-el sendiri diluncurkan pada Februari 2011, kemudian pelaksanaannya dibagi menjadi dua tahap. Tahap pertama dimulai pada bulan Februari tahun tersebut dengan batas akhir bulan April di tahun 2012. Tahap selanjutnya ditargetkan hingga akhir tahun 2012. Namun, hingga saat ini proyek tersebut tidak kunjung rampung dan KTP-el belum dapat berlaku secara efektif karena masih banyaknya warga yang belum memiliki KTP-el.

Sebagai contoh, di Palembang, hingga Agustus 2014, baru sekitar $84 \%$ warga yang telah melakukan perekaman data untuk KTP-el. Kementerian Dalam Negeri sendiri sebenarnya menargetkan penyelesaian perekaman data di setiap daerah pada akhir Juli. Namun di Palembang, meskipun jumlah warga yang wajib KTP-el adalah sebanyak 1.275.294 jiwa, yang baru merekam data hanya sebesar 1.014.814 jiwa. Kepala Dinas Pencatatan Sipil Palembang, Ali Subri mengatakan bahwa masih banyak warga yang menganggap KTP-el tidak penting, sehingga belum juga melakukan perekaman data. Selain daripada itu, kendala teknis juga sering terjadi, yakni mesin perekaman yang sering error, sehingga perekaman terganggu dan menimbulkan tumpukan antrean pembuat KTP-el. Dari 1.014.814 jiwa yang telah melakukan perekaman data pun tidak seluruhnya sudah mendapatkan KTP-el. Proses pencetakan dan distribusi masih dilakukan secara langsung dari instansi pemerintah pusat, sehingga untuk KTP-el yang belum didistribusikan, sisanya masih menunggu dari pemerintah pusat. ${ }^{32}$

Belum lama ini, Ombudsman Republik Indonesia mendesak Kementerian Dalam Negeri untuk memperbaiki layanan terhadap KTP-

${ }^{31}$ Kadisdukcapil DKI: Proyek E-KTP Kacau Balau, <http://wartakota.tribunnews.com/ 2014/04/24/kadisdukcapil-dki-proyek-e-ktp-kacau-balau>, diakses pada tanggal 24 April 2014.

${ }^{32}$ Dianggap tak penting, perekaman e-KTP di Palembang baru $84 \%$, diakses dari $<$ http://www.merdeka.com/peristiwa/dianggap-tak-penting-perekaman-e-ktp-di-palembangbaru-84-.html>, diakses pada tanggal 28 Agustus 2014. 
el. Komisioner Ombudsman Bidang Penyelesaian Laporan, Budi Santoso, mengatakan bahwa pihak Ombudsman menemukan sejumlah maladministrasi dalam pelayanan KTP-el, yang diantaranya disebabkan oleh masalah infrastruktur, ketidakpastian lamanya waktu pencetakan, dan prosedur perbaikan data KTP-el. Temuan terkait maladministrasi ini diperoleh dari pemantauan penyelenggaraan KTP-el di wilayah Jabodetabek pada pertengahan hingga akhir September lalu. Menurut pihak Ombudsman, apabila Kemendagri mengalami kesulitan dalam hal pencetakan KTP-el, hal tersebut harus dapat dikomunikasikan kepada instansi pemerintah di kelurahan, sehingga dapat diinformasikan ke masyarakat. Dari temuan yang diperoleh, diketahui bahwa beberapa kelurahan, kecamatan, bahkan dinas, tidak mengetahui update informasi dari pencetakan KTP-el oleh Kemendagri. Mengenai hal ini, pihak Kemendagri menanggapi dengan menyatakan bahwa ketidakpastian layanan KTP-el yang terjadi diakibatkan kelemahan pihaknya dalam menyosialisasikan perkembangan informasi KTP-el. ${ }^{33}$

\section{Langkah Strategis Proyek KTP-el}

Kementerian Dalam Negeri menyatakan bahwa penerapan KTP-el hingga saat ini sudah mencapai $80 \%$, yakni telah mencapai 145.000 .000 penduduk yang sudah terjamin ketunggalannya dari target 245.609.453 penduduk. Untuk mencapai target $100 \%$ penerapan KTP-el, mulai tahun 2014 ini pemerintah berencana melaksanakan suatu langkah strategis yakni melalui penyerahan wewenang untuk pencetakan KTP-el kepada pemerintah kabupaten/kota. Selama ini, pemerintah kabupaten/kota terlibat hanya dalam pelaksanaan perekaman data warga di wilayahnya, untuk kemudian data tersebut dikirimkan kepada instansi pusat untuk verifikasi ketunggalan identitas. Setelah identitas telah dipastikan tunggal, maka instansi pusat selanjutnya akan mencetak KTP-el warga tersebut. Selanjutnya, KTP-el yang telah tercetak didistribusikan kembali kepada warga. Penyerahan wewenang untuk pencetakan KTP-el di tingkat kabupaten/kota ini dikatakan untuk mendekatkan pelayanan kepada masyarakat, sesuai dengan amanah Undang-Undang Nomor 24 Tahun 2013 tentang Perubahan Undang-Undang Nomor 23 Tahun 2013 tentang Perubahan Undang-Undang Nomor 23 Tahun 2006 tentang Administrasi Kependudukan ${ }^{34}$. Upaya ini merupakan bagian dari langkah percepatan penerapan KTP-el di tahun 2014. Selain itu, pemerintah juga

33 Kemendagri Diminta Perbaiki E-KTP, <http://www.republika.co.id/berita/koran/ kesra/14/10/09/nd69rt-kemendagri-diminta-perbaiki-ektp>, diakses pada tanggal 9 Oktober 2014.

${ }^{34}$ M.Y. Raso dan Yunita Imelda, Permasalahan di Sekitar Pencetakan E-KTP Secara Nasional, Sekretariat Kabinet Republik Indonesia, <http://setkab.go.id/artikel-12603permasalahan-di-sekitar-pencetakan-e-ktp-secara-nasional.html>, diakses pada tanggal 29 Maret 2014. 
telah melakukan koordinasi antar instansi dan antar daerah, membentuk sistem, pedoman, dan standar, serta melakukan pembinaan, pembimbingan, supervisi, pemantauan, evaluasi dan konsultasi kepada pemerintah daerah kabupaten/kota. Selain itu Sistem Informasi Administrasi Kependudukan (SIAK) yang akan tersambung secara online dengan semua kabupaten/kota dan kecamatan untuk database kependudukan juga sedang dikembangkan. ${ }^{35}$ Direktur Jenderal Kependudukan dan Catatan Sipil Kemendagri menyatakan bahwa sekitar November atau Desember 2014, pencetakan KTP-el sudah bisa dimulai kembali dengan kewenangan pencetakan pada tingkat kabupaten/kota menggunakan APBNP. ${ }^{36}$

Untuk melaksanakan langkah ini, beberapa hambatan masih dijumpai, yakni: masih belum dilakukannya pendistribusian blanko KTPel ke kabupaten/kota, ${ }^{37}$ kemudian jumlah dan kualifikasi tenaga operator yang disiapkan untuk pelayanan KTP-el masih kurang bahkan ada beberapa kabupaten belum mempunyai tenaga operator, sehingga diperlukan perekrutan tenaga operator untuk melakukan pelayanan KTPel. Selain itu masih kurangnya peralatan yang diberikan di daerah-daerah perbatasan seperti di Kalimantan Barat, Kalimantan Timur, dan Kepulauan Riau serta ketersediaan daya listrik diseluruh kecamatan/tempat pelayanan KTP-el se-kabupaten/kota tersebut belum memadai dikarenakan anggaran untuk pembelian genset belum mencukupi, biaya bahan bakar relatif mahal dan susah dijangkau, serta memerlukan waktu yang lama dalam proses pengadaan pembelian genset. $^{38}$

Selain itu, Direktur KTP-el Kementerian Dalam Negeri, Sugiharto, menyatakan bahwa kendala lain untuk pencetakan KTP-el oleh kabupaten/kota adalah juga berkenaan dengan anggaran. Anggaran tersebut dialokasikan dalam APBN Perubahan 2014, namun APBN tersebut belum tersedia, sehingga pencetakan di kabupaten/kota belum bisa dimulai. Anggaran yang tersedia hingga tahun 2014 pun baru untuk sekitar 172 juta penduduk dari target 192 juta, sehingga untuk sekitar 19 juta penduduk belum teranggarkan. ${ }^{39}$ Di Jakarta sendiri, Kepala Dinas

${ }^{35}$ Ibid.

${ }^{36}$ Kemendagri Diminta Perbaiki E-KTP, Loc. Cit.

37 Sebagai contoh di Surabaya: Pencetakan E-KTP Sulit Terealisasi, <http://www.jpnn.com/read/2014/04/25/230717/Pencetakan-E-KTP-Sulit-Terealisasi-\#>, diakses pada tanggal 25 April 2014.

${ }^{38}$ Ibid.

39 Andreas Piatu, Program e-KTP, Proyek Gagal yang Diserahkan pada Daerah?, $<$ http://sinarharapan.co/news/read/33351/program-ektp-proyek-gagal-yang-diserahkan-padadaerah>, diakses pada tanggal 4 Maret 2014. 
Kependudukan dan Catatan Sipil DKI Jakarta, Purba Hutapea, menyatakan bahwa alat yang disediakan Kementerian Dalam Negeri belum dapat memenuhi kebutuhan percetakan KTP-el. Printer yang disediakan untuk cetak hanya dua unit di satu kota. Selain masalah alat, untuk pengecekan data kependudukan yang akan dicetak KTP-elnya, sistem jaringan Kementerian Dalam Negeri juga sepertinya belum memadai. Sampai saat ini belum ada standar operasional prosedur (SOP) yang menyebutkan jaringan tersebut harus tetap online, dan lama pengembalian data dari pusat ke daerah untuk memastikan data sudah benar pun belum jelas waktunya. Pertanyaan lain pun muncul terkait sisa KTP-el yang harusnya dicetak dan didstribusikan oleh instansi pusat sebelum wewenang pencetakan diserahkan ke kabupaten/kota, apakah sisa KTP-el itu akan tetap dicetak oleh instansi pusat, atau akan juga diserahkan kepada kabupaten/kota. ${ }^{40}$ Lalu juga KTP-el yang salah cetak, apakah kemudian akan dikembalikan lagi ke intansi pusat atau menjadi tanggung jawab kabupaten/kota untuk perbaikan.

\section{Penyimpangan dalam Penerapan KTP-el}

Ditemukannya sejumlah KTP-el yang salah cetak agaknya mengindikasikan kesalahan teknis atau ketidaksiapan sistem dalam penerapan KTP-el. Begitu pula dengan penanganan kesalahan cetak tersebut dan kejelasan informasi mengenai kapan warga yang KTP-el nya salah cetak dapat menerima KTP-el yang telah diperbaiki. ${ }^{41}$ Selain itu, juga ditemukan KTP-el yang rusak. Di Kabupaten Bangkalan, Jawa Timur, sejumlah warga menerima KTP-el yang rusak. Kepala Bidang Administrasi, Dinas Kependudukan dan Catatan Sipil setempat, Jayus Sayuti, mengatakan bahwa di Kabpuaten Bangkalan sendiri, KTP-el yang rusak mencapai 300 (tiga ratus) kartu yang tersebar di 18 kecamatan. Salah satu warga di Desa Keleyan, Kecamatan Socah, Bangkalan Husen, sudah 1 (satu) tahun menunggu perbaikan KTP-el yang rusak, namun hingga saat ini belum menerima KTP-el perbaikan yang baru. Karena masalah ini, akhirnya warga penerima KTP-el rusak membuat KTP biasa terlebih dahulu, dan nantinya diharapkan Pemerintah Kabupaten dapat melakukan perbaikan terhadap KTP-el rusak yang dimiliki oleh warga berdasarkan pelimpahan wewenang pembuatan KTP-el dari pemerintah pusat kepada pemerintah daerah. ${ }^{42}$

${ }^{40}$ Ibid.

${ }^{41}$ Sebagai contoh di Bandung dan Kecamatan Pengadegan: Salah Cetak, 5.685 E-KTP Dikembalikan, <http://www.antarajateng.com/detail/index.php?id=74585>, dan E-KTP Salah Cetak, Distribusi Kacau diakses dari <http://koran-sindo.com/node/311049>.

42 Baru Diberikan, KTP Elektronik Warga Bangkalan Banyak yang Rusak, <http://www.merdeka.com/peristiwa/baru-diberikan-ktp-elektronik-warga-bangkalan-banyakyang-rusak.html>, diakses pada tanggal 28 Mei 2014. 
Kesalahan pengiriman/distribusi KTP-el juga terjadi di beberapa daerah. Sebagai contoh, sebanyak 30 (tiga puluh) lembar KTP-el milik warga Kabupaten Boven Digoel, Propinsi Papua, dikirim ke Kabupaten Muara Enim, Sumatera Selatan. Selain itu, KTP-el milik warga Kabupaten Gunung Kidul, DI Yogyakarta, juga salah kirim ke Kabupaten Muara Enim. Sebaliknya, sebanyak 50 (lima puluh) lembar KTP-el milik warga Kabupaten Muara Enim juga pernah nyasar ke Kabupaten Ogan Komering Ulu, Sumatera Selatan. Untuk KTP-el yang salah kirim tersebut, oleh mereka dikembalikan ke Ditjen Kependudukan dan Pencatatan Sipil, Kementerian Dalam Negeri. ${ }^{43}$

Selain itu, juga ditemukan masih banyaknya Pegawai Negeri Sipil yang melakukan pungutan liar (pungli) kepada masyarakat yang hendak mengurus KTP-el. Kementerian Dalam Negeri mengakui masih banyak menerima laporan adanya praktik pungli dalam pengurusan KTP-el di beberapa daerah. Hal ini bertentangan dengan Undang-Undang Administrasi Kependudukan yang menyatakan bahwa KTP-el berlaku seumur hidup dan pengurusannya tidak dipungut biaya. Berdasarkan ketentuan Undang-Undang tersebut, terhadap setiap pejabat dan petugas pada desa atau kelurahan atau kecamatan atau unit pelaksana teknis instansi pelaksana dan instansi pelaksana yang memerintahkan dan atau memfasilitasi dan atau melakukan pungutan biaya kepada penduduk dalam pengurusan dan penerbitan KTP-el tersebut, dapat dipidana dengan pidana penjara paling lama 6 tahun dan atau denda paling banyak Rp 75 juta. $^{44}$

Kemudian, proyek KTP-el juga tersandung dugaan kasus korupsi. Dugaan ini terkait penggunaan teknologi dalam KTP-el yang tidak sesuai dengan spesifikasi awal. Wakil Ketua Komisi Pemberantasan Korupsi (KPK), Bambang Widjojanto, menyatakan bahwa salah satu bentuk penyelewengan yang ditemukan oleh KPK adalah penggunaan teknologi chip dalam KTP-el, dimana terjadi penurunan kualitas atas teknologi tersebut, yang harusnya pirantinya berkemampuan iris technology, namun dalam pelaksanaannya hanya berkemampuan finger technology (finger print). Hal ini tidak sesuai seperti yang ada di dalam kontrak tender. Untuk kasus ini, KPK menetapkan Pejabat Pembuat Komitmen (PPK) KTP-el, Sugiharto, sebagai tersangka. ${ }^{45}$ Sugiharto diduga melakukan penyalahgunaan wewenang yang mengakibatkan kerugian

43 Puluhan Lembar e-KTP Papua Nyasar ke Sumsel, <http://www.merdeka.com/ peristiwa/puluhan-lembar-e-ktp-papua-nyasar-ke-sumsel.html>, dan Selain Papua, Sumsel Juga Pernah Terima e-KTP Nyasar dari DIY, <http://www.merdeka.com/peristiwa/selainpapua-sumsel-juga-pernah-terima-e-ktp-nyasar-dari-diy.html $>$, diakses pada tanggal 28 Mei 2014.

${ }^{44}$ Mendagri Akui Pungli E-KTP Masih Marak, Loc. Cit.

45 Teknologi e-KTP Tak Sesuai Spesifikasi, <http://www.jpnn.com/read/2014/04/ 25/230576/Teknologi-e-KTP-Tak-Sesuai-Spesifikasi->, diakses pada tanggal 25 April 2014. 
negara terkait pengadaan proyek KTP-el tersebut. KPK menjerat Sugiharto dengan Pasal 2 ayat 1 subsider Pasal 3 Undang-Undang Pemberantasan Tindak Pidana Korupsi juncto Pasal 55 Ayat 1 ke-1 juncto Pasal 64 Ayat 1 KUHPidana. Komisaris PT Mecosuprin Grafia, Yoedono Gunawan, dan Bagian Purchasing dari PT Sandipala Arthapura, Subagio Limantara, yang merupakan bagian dari konsorsium pengadaan proyek e-KTP, juga dipanggil oleh KPK untuk menjadi saksi dalam kasus ini. ${ }^{46}$

\section{KTP-el untuk Pelayanan Publik dan Pemilihan Umum}

Terkait pengembangan penggunaan KTP-el, Direktur Pusat Teknologi Informasi dan Komunikasi (PTIK) Badan Pengkajian dan Penerapan Teknologi (BPPT), Hammam Riza, menyatakan bahwa untuk generasi selanjutnya dari KTP-el, selain menjadi kartu identitas, juga diharapkan dapat dimanfaatkan untuk jaminan kesehatan dan jaminan sosial. Selain itu juga dapat digunakan untuk meningkatkan keamanan negara, dikarenakan berbagai kejahatan yang bersumber dari data identitas yang palsu atau ganda dapat diketahui. Selain itu, pengembangan juga akan diarahkan untuk mendorong dan memanfaatkan KTP-el untuk pemilihan umum secara elektronik atau $e$-voting. Hingga saat ini, BPPT sudah mulai merancang aplikasi generasi kedua KTP-el yang diharapkan dapat difungsikan untuk pelayanan publik dan $e$-voting tersebut. $^{47}$

Namun, masih ditemui beberapa kesulitan dalam pemanfaatan KTPel untuk pendataan daftar pemilih dalam pemilihan umum. Sebagai contoh, pemilihan bupati di Kabupaten Kediri mendasarkan data dan jumlah pemilih berdasarkan data KTP-el. Data penduduk dalam KTP-el dijadikan sebagai acuan utama untuk menentukan daftar pemilih tetap (DPT) pemilihan Bupati Kediri tahun 2015 mendatang. Sehingga, apabila perekaman dan pengadaan KTP-el tersebut belum tuntas, hal ini menimbulkan potensi untuk dimanfaatkannya data masyarakat oleh oknum tertentu untuk berbuat curang dalam pemilihan Bupati tersebut. Anggota KPU Kabupaten Kediri, Syamsuri, menyatakan bahwa belum tuntasnya program KTP-el dapat memicu kerancuan data pemilih, dan warga yang belum memiliki KTP-el bisa kehilangan hak pilihnya.

${ }^{46}$ Komisaris PT Mecosuprin Grafia Diperiksa KPK, <http://news.metrotvnews.com/ $\mathrm{read} / 2014 / 06 / 25 / 257076 /$ komisaris-pt-mecosuprin-grafia-diperiksa-kpk>, diakses pada tanggal 25 Juni 2014.

47 E-KTP, E-Voting dan Penerapannya, BPPT.GO.ID, <http://www.bppt.go.id/ index.php/home/46-umum/1324-orientasikan-pembangunan-ekonomi-berlandaskankemampuan-iptek>, diakses pada tanggal 25 Juni. 
Hingga saat ini masih banyak warga di Kabpuaten Kediri yang belum memiliki KTP-el meskipun sudah melakukan perekaman data. ${ }^{48}$

Menyusul kerjasama Kementerian Dalam Negeri dengan Kementerian Pendayagunaan Aparatur Negara untuk menjadikan KTP-el sebagai salah satu persyaratan untuk pendaftaran CPNS, ${ }^{49}$ belum selesainya pencetakan dan distribusi KTP-el untuk warga yang telah melakukan perekaman data juga menimbulkan kesulitan bagi warga yang bersangkutan. Di Solo, sedikitnya sekitar 25.000 keping KTP-el warga hingga kini belum juga rampung, padahal perekaman data telah dilakukan sejak 2013 lalu. Kepala Seksi Identias Penduduk, Dinas Kependudukan dan Catatan Sipil (Dispendukcapil) Kota Solo, Subandi, mengatakan sudah berulang kali melaporkan hal tersebut ke Pemerintah Pusat, namun hingga kini belum ada kejelasan mengenai hal tersebut. Untuk mengakomodir kebutuhan warga yang memerlukan KTP-el contohnya untuk pendaftaran CPNS, Dispendukcapil Solo membuka loket khusus untuk melayani surat keterangan kependudukan bagi warga yang belum menerima KTP-el. ${ }^{50}$ Keluhan persyaratan KTP-el untuk CPNS juga dilontarkan oleh warga Bali yang belum menerima KTP-el hingga saat ini, meskipun sudah melakukan perekaman data 1-2 tahun yang lalu. ${ }^{51}$

\section{Top of Form}

\section{a. Pemanfaatan Data Penduduk via Koneksitas Data Warehouse dan Biometrik}

Dalam situs resmi kementrian dalam negeri, khususnya pada beranda e-KTP dicantumkan bahwa pada tahun 2013 telah mulai dibuka akses data penduduk kepada instansi Pemerintah dan Lembaga Negara sesuai dengan aturan perundang-undangan. Data penduduk digunakan untuk berbagai kepentingan pembangunan

48 E-KTP Belum Tuntas, Daftar Pemilih Bupati Kediri Terancam Kacau, <http://www.merdeka.com/peristiwa/e-ktp-belum-tuntas-daftar-pemilih-bupati-kediriterancam-kacau.html>, diakses pada tanggal 30 Agustus 2014

49 Kemendagri: Syarat CPNS Harus Punya e-KTP, merdeka.com, diakses dari $<$ http://www.merdeka.com/uang/kemendagri-syarat-cpns-harus-punya-e-ktp.html>, diakses pada tanggal 25 Agustus 2014.

5025 Ribu e-KTP Warga Solo Belum Jadi, Pendaftaran CPNS Terganggu, <http://www.merdeka.com/peristiwa/25-ribu-e-ktp-warga-solo-belum-jadi-pendaftaran-cpnsterganggu.html>, diakses pada tanggal 26 Agustus 2014.

51 Tak Punya e-KTP, Ribuan Warga Bali Mengeluh Tak bisa Ikut CPNS, <http://www.merdeka.com/peristiwa/tak-punya-e-ktp-ribuan-warga-bali-mengeluh-tak-bisaikut-cpns.html>, diakses pada tanggal 21 Agustus 2014. 
dengan memperhatikan aspek kerahasiaan data yang bersifat privasi. Dalam hal akses data dilakukan dengan sangathati-hati dan dilandasi dengan UU, Nota Kesepahaman (MOU) dan Perjanjian Kerja Sama (PKS).

Nota Kesepahaman dan Perjanjian Kerja Sama yang telah direalisir meliputi:

\begin{tabular}{|c|c|}
\hline Nota Kesepahaman & Perjanjian Kerjasama \\
\hline $\begin{array}{l}\text { 1. Komisi Pemilihan Umum (melalui UU } \\
\text { Pemilu No.8 Tahun 2012). } \\
\text { 2. Menteri Hukum dan HAM. } \\
\text { 3. Menteri Keuangan. } \\
\text { 4. Menteri Tenaga Kerja dan } \\
\text { Transmigrasi. } \\
\text { 5. Menteri Badan Usaha Milik Negera } \\
\text { (BUMN). } \\
\text { 6. Menteri Kesehatan. } \\
\text { 7. Menteri Komunikasi dan Informatika. } \\
\text { 8. Menteri Perencanaan Pembangunan } \\
\text { Nasional/Kepala Bappenas. } \\
\text { 9. Kepala Kepolisian Republik Indonesia. } \\
\text { 10. Kepala Badan Nasional Penempatan } \\
\text { dan Perlindungan Tenaga Kerja } \\
\text { Indonesia/BNP2TKI. } \\
\text { 11. Deputi Sekretaris Wakil Presiden } \\
\text { Bidang Kesejahteraan Rakyat dan } \\
\text { Penanggulangan Kemiskinan Selaku } \\
\text { Sekretaris Eksekutif Tim Nasional } \\
\text { Percepatan Penanggulangan } \\
\text { Kemiskinan/TNP2K. } \\
\text { 12. PPATK. }\end{array}$ & $\begin{array}{l}\text { 1. PT AS } \\
\text { 2. PT JAMSOSTEK Pesero/BPJS } \\
\text { Ketenagakerjaan. } \\
\text { 3. KES Pesero/BPJS Kesehatan. } \\
\text { 4. TNP2K. } \\
\text { 5. Ditjen Pajak. } \\
\text { 6. Bank Mandiri. } \\
\text { 7. BNI. } \\
\text { 8. BRI. } \\
\text { 9. POLRI (Bareskrim). } \\
\text { 10. Kemenkes. } \\
\text { 11. } \text { BNP2TKI. }\end{array}$ \\
\hline
\end{tabular}

Sementara untuk PKS yang masih dalam proses adalah:

(1) KPK (ujicoba akses data terbatas);

(2) PPATK (ujicoba akses data terbatas);

(3) BKN (ujicoba akses data dalam proses penerimaan CPNS 2013);

(4) BANK INDONESIA (Penyusunan skema teknis kerja sama);

(5) Kemenkoinfo (Penyusunan skema teknis kerja sama).

Dinyatakan bahwa Sumber data yang dipergunakan dalam pelaksanaan koneksitas datawarehouse adalah data hasil integrasi antara data penduduk SIAK dan dan KTP elektronik.Sumber data Warehouse adalah data hasil pelayanan (registrasi) pendaftaran penduduk dan pencatatan sipil dari seluruh Kab/Kota yang telah dihimpun dalam database kependudukan nasional dan dibersihkan atau dilakukan afgrid data setiap satu semester yakni bulan Juni dan 
bulan desember secara rutin dan kesinambungan. Data penduduk memerlukan update secara rutin karena data penduduk bersifat dinamis, bergerak. Penduduk selalu mengalami peristiwa kependudukan dan pencatatan sipil dari waktu ke waktu seperti lahir, mati, pindah dan datang serta perubahan status sesuai dengan kepentingannya. Data warehouse mencakup seluruh data penduduk dari usia 0 tahun sampai dengan penduduk usia dewasa dan usia lanjut. Menu atau jenis data yang diakses mencakup data individu (by name by address), data agregat dan tipologi data lain yang diperlukan sepanjang diatur dalam perundangan.

Diuraikan bahwa Data biometrik adalah data penduduk yang disertai dengan ciri-ciri tubuh berupa sidik jari, iris mata dan wajah. Data biometrik hanya mengidentifikasi data penduduk yang telah melakukan perekaman biometrik yakni usia wajib KTP ke atas. Menu atau jenis data yang diakses adalah data biometrik penduduk untuk kepentingan akurasi atau pemadanan terhadap suatu peristiwa pelayanan publik dan pembangunan serta keamanan berdasarkan perundangan yang berlaku.

Sedangkan terkait dengan Akses data juga dinyatakan bahwa:

(1) Akses data dengan menggunakan pelayanan akses data berbasis web service, yaitu sebuah sistem pencarian dan pengiriman data dengan menggunakan platform data universal berbasis teks. Data yang dihasilkan dapat dikombinasikan dan diolah kembali oleh aplikasi milik instansi/lembaga pemanfaat. $^{52}$

(2) Akses data dengan menggunakan web service dan ditampilkan secara statis dengan aplikasi website portal yang disediakan oleh Ditjen Dukcapil, sehingga instansi/lembaga pemanfaat tidak perlu memiliki aplikasi sendiri.

(3) Pemadanan data secara offline, digunakan untuk pemuktahiran data instansi pemanfaat secara offline yang dilakukan pada saat pertama kali pemanfaat akan menggunakan koneksitas datawarehouse, hal ini dimaksudkan sebagai alternatif untuk mengurangi beban akses online saat pemuktahiran data awal. Akses selanjutnya dilkakukan secara online dengan asumsi jumlah data yang mengalir lebih sedikit.

(4) Pencarian data penduduk secara manual, dilakukan untuk mencari data penduduk tertentu yang memerlukan metode khusus dalam pencariannya. Hal ini dilakukan untuk kepentingan penyidikan dan sebagainya.

\footnotetext{
${ }^{52}$ Fasilitas web service saat ini sudah tersedia dalam dua skema yaitu:Web Service Definition Language (WSDL).Sumber Data: Integrasi data eKTP dan SIAK, Jalur Akses: VPN only, Metode: Call by NIK, Output: Data Individu dan data keluarga. Jumlah User: (Detail, lihat file Usermaster.xlsx).
} 
(5) Akses data biometrik menggunakan aplikasi biometrik yang dapat digunakan mengakses profil biometrik penduduk secara lengkap. Pengguna utama biometrik adalah lembaga kepolisian dan lembaga lain berdasarkan perundang-undangan.

(6) Pelaksanaan akses data dilakukan oleh Tim Teknis Ditjen Dukcapil dan Tim Teknis dari para pengguna data yang diatur dalam sebuah Standar Prosedur Operasional (SPO/SOP). ${ }^{53}$

Terkait dengan pengaturan akses, diuraikan bahwa Pengaturan hak akses untuk dapat memanfaatkan koneksitas datawarehouse kependudukan berbasis NIK, dan laporan statistik berbasis business intelligence dibentuk dalam sebuah prosedur yang menjadi bagian dari standar operasional dan prosedur koneksitas datawarehouse. Prosedur hak akses tersebut adalah:

(1) Pengguna harus mengajukan permohonan hak akses terhadap seluruh user yang ada dalam lingkungan instansinya yang akan menjadi pengguna akses data kependudukan kepada menteri dalam negeri;

(2) Dalam pengajuan hak akses, instansi pengguna wajib mencantumkan Kode wilayah kantor tempat user tersebut bertugas (sampai dengan kecamatan), NIK, Nomor induk pegawai, Nama user, jabatan dan user ID dari aplikasi local atau client tool;

(3) Setelah pengajuan hak akses disetujui, instansi pengguna akan menerima sejumlah user id dan password dari Kementerian Dalam Negeri dengan disertai berita acara;

(4) Setiap pengaksesan data kependudukan melalui web service oleh user, wajib di catat dalam sebuag log system, dan log system ini akan menjadi bahan acuan evaluasi pemanfaatan akses data kependudukan dengan web service;

(5) Setiap ada perubahan kondisi user atau penambahan atau penghapusan user, instansi pengguna wajib memberitahukan

53 SOP adalah rincian prosedur kerja sama secara teknis, yang memuat tahap demi tahap dalam pelaksanaan koneksitas di kedua belah pihak. SOP disusun oleh tim teknis kedua belah pihak dengan memperhatikan koridor-koridor kerja sama teknis yang termuat dalam PKS. SOP bersifat fleksibel, mengadaptasi kebutuhan dari kedua belah pihak, dan dapat disesuaikan dengan perkembangan kerja sama. Instansi-instansi pemanfaat yang sudah menyusun SOP bersama Direktorat Jenderal Kependudukan dan Pencatatan Sipil, adalah:

1. PT Jamsostek (Persero)/BPJS Ketenagakerjaan;

2. PT Askes (Persero)/ BPJS Kesehatan;

3. Direktorat Jenderal Pajak;

4. PT Bank Rakyat Indonesia (Persero), Tbk.;

5. Kementerian Kesehatan;

6. BNP2TKI;

7. Bank Mandiri. 
secara resmi kepada kementerian dalam negeri;

(6) Penyimpangan atas penggunaan hak akses, akan dikenakan sanksi pemutusan sementara oleh kementerian dalam negeri.

Selanjutnya berdasarkan pelaksanaan pemanfaatan data kependudukan tersebut, Kemdagri mengidentifikasi beberapa hal yang dinilai dapat dijadikan bahan evaluasi sebagai berikut:

(1) Pemanfaatan data yang dinilai telah aktif sepenuhnya pada tahun 2013 adalah Jamsostek, menyusul lembaga lainnya yakni, PPATK, KPK, PT ASKES. Sejauh ini akses data berjalan lancar. Akan tetapi pada tahun 2014 diperkirakan semua lembaga pengguna, akan melakukan akses penuh sehingga memerlukan fasilitasi kapasitas berupa pengukuran daya dukung perangkat lunak dan perangkat keras (server dan exadata serta peningkatan KVA daya listrik). Untuk mengantisipasi hal tersebut, saat ini BRI telah memberikan server di ruang DC Dukcapil;

(2) Untuk menyempurnakan SOP menjadi dokumen legal berupa penandatanganan oleh para pihak, saat ini SOP telah yang tersusun dan telah ditanda tangani oleh ke dua belah pihak yakni SOP PT ASKES. Untuk itu, SOP yang lain akan segera dilakukan penanda tanganan setelah dikoordinasikan dan disesuaikan berdasarkan kebutuhan teknis. Seperti dimaklumi, bahwa SOP adalah bagian kelanjutan dari PKS yang menjadi acuan teknis akses data oleh pengguna;

(3) Kominfo merupakan salah satu pengguna data yang telah memiliki MOU dan PKS (dalam proses). Dalam hal pemanfaatan data, lembaga ini merencanakan 2 pola akses data yakni: (i) sebagai pemanfat data untuk kepentingan layanan intern seperti prabayar dan seterusnya; dan (ii) sebagai fasilitator, yakni fasilitasi untuk pengguna oleh lembaga lain. Hal ini dilakukan sejalan dengan aturan perundangan Kominfo, disamping Kominfo telah memiliki infrastruktur yang kuat untuk fasilitasi akses data secara nasional.Tentu dalam kontek ini ada aspek negatif dan positif. Untuk itu, perlu adanya telaah dan kebijakan pimpinan lebih lanjut;

(4) Tim teknis Koneksitas Data memerlukan penetapan berupa SK TIM. Saat ini Tim teknis telah ada berdasarkan penunjukan hasil Rapat teknis ketika penyusunan PKS dengan PT ASKES tahun 2013, tetapi belum dibakukan ke dalam bentuk SK TIM. Untuk itu, pada tahun 2014, TIM teknis perlu di sesuaikan dan TIM teknis perlu dilandasi dengan SK TIM;

(5) Ditjen Imigrasi yang telah memiliki MOU, akan tetapi sepanjang tahun 2013 dinilai tidak aktif. Untuk itu, perlu adanya alternatif, apakah pada tahun 2014, VPN dialihkan dulu pada pengguna lainnya; 
(6) Kemendiknas, saat ini telah terpasang VPN akan tetapi belum dilakukan MOU maupun PKS. Dari hasil koordinasi, pihak Diknas mengharapkan agar VPN untuk tahun 2014 tidak diputus karena tahun 2014 akan dimanfaatkan untuk mendukung program yang baru dimulai tahun 2014. Sedangkan untuk MUO dan PKS akan dikoordinasikan dengan pihak pimpinan;

(7) Koneksitas data dengan POLRI, disamping dilakukan melalui BARESKRIM sebagai pintu gerbang perwakilan POLRI, akan tetapi berdasarkan hasil temu teknis dengan para Kadisdukcapil, di daerah sering ada permintaan pemadanan atau pencarian data penduduk dari Polda setempat."

Berdasarkan uraian tersebut diatas, diketahui bahwa SIAK telah mulai di interaksikan dengan pihak atau instansi lain. Namun masih menjadi pertanyaan besar sejauhmana SOP untuk menjamin kebersihan data yang ada pada SIAK. Sementara audit eksternal tampaknya masih belum dilakukan. Satu hal yang dapat menjamin validitas data yang diberikan secara "physical presence" adalah sama dengan yang digunakan secara "physical presence" pula adalah pada saat SIAK dapat diakses untuk menjadi fasilitas mengautentikan oleh Notaris selaku pejabat umum, ironisnya hal tersebut masih belum ada MOU ataupun PKS antara Kemdagri dengan Ikatan Notaris Indonesia. Dengan kata lain, hal itu masih mengindikasikan belum ada jaminan validitas data bahwa data yang telah diberikan secara kehadiran fisik adalah sama dengan penggunaannya secara fisik. Idealnya, selain PKS dengan Kominfo, justru PKS dengan Notaris lah yang seharusnya menjadi prioritas terlebih dahulu bagi Kemdagri sebelum melakukan MOU atau PKS dengan pihak lainnya.

\section{Beberapa National Digital Identity di Eropa}

Dalam perkembangannya sekarang ini, Eropa sedang berusaha untuk mengembangkan suatu sistem yang dapat mengenali identitas dari seluruh warga Eropa, lintas antar negara anggota. Sistem tersebut disebut dengan STORK Project (Secure Identity Across Border Linked), khususnya untuk menentukan tingkatan Quality of Assurance Level dari sertifikat dan tanda tangan elektronik dari masing-masing Negara anggota (level 1 untuk no assurance or minimal level, level 2 untuk low level, level 3 untuk substantial level, dan level 4 untuk high level). Selanjutnya mereka memperhatikan QAA tersebut dengan memperhatikan proses registrasi dan proses autentikasinya. 


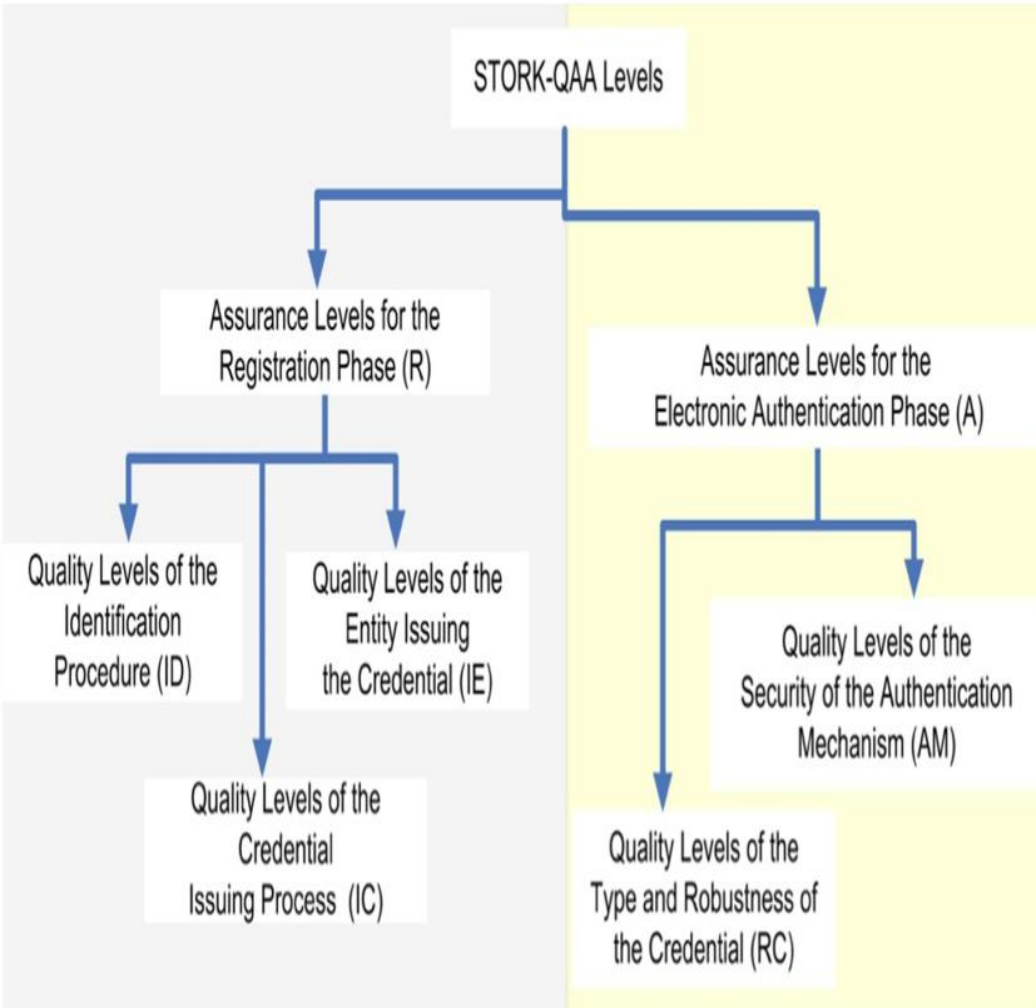

Dengan berdasarkan pola QAA tersebut, masih dengan mengacu kepada Diective 1999/93/EC mereka melakukan table komparasi dari masing-masing Negara anggota untuk dapat melihat interoperabilitasnya.

\begin{tabular}{|l|l|l|l|l|l|l|l|l|l|}
\hline & $\begin{array}{l}\text { \# of } \\
\text { cred. }\end{array}$ & $\begin{array}{l}\text { Smart } \\
\text { card }\end{array}$ & $\begin{array}{l}\text { mobile } \\
\text { eID }\end{array}$ & $\begin{array}{l}\text { soft. } \\
\text { certif. }\end{array}$ & $\begin{array}{l}\text { qualified cert } \\
\text { (signature-cert) }\end{array}$ & is a SSCD & public sector & private sector \\
\hline Austria & 3 & yes & yes & - & all & all & yes & yes (all. qual.c.) \\
\hline Belgium & 1 & yes & - & - & all & all & yes & - \\
\hline Estonia & 2 & yes & yes & - & all & all & yes & - \\
\hline Germany & 1 & yes & - & - & optional & all & yes & (opt. qual.certs.) \\
\hline Finland & 1 & yes & - & - & qualified & all & yes & - \\
\hline Iceland & 2 & yes & - & - & all & all & - & yes \\
\hline Italy & 2 & yes & - & - & all & all & yes & yes (sig.card) \\
\hline Lithuania & 1 & yes & - & - & all & all & yes & - \\
\hline Luxembourg & 3 & yes & yes & - & all & all & - & yes \\
\hline Portugal & 1 & yes & - & - & all & all & yes & - \\
\hline Slovenia & 3 & yes & - & yes & all & yes (QAA 4) & yes & yes \\
\hline Spain & $1+80$ & yes & - & yes & all & yes (QAA 4) & yes (QAA 3-4) & yes (QAA3-4) \\
\hline Sweden & $12+$ & yes & yes & yes & - & tbc & yes & yes \\
\hline
\end{tabular}


Melihat hal tersebut di atas maka dapat dikatakan bahwa manfaat STORK Project tidak hanya berhubungan dalam konteks regional Eropa melainkan juga internasional.

Secure idenTity acrOss boRders linKed 2.0 will contribute to the realization of a single European electronic identification and authentication area. It does so by building on the results of STORK, establishing interoperability of different approaches at national and EU level, eID for persons, eID for legal entities and the facility to mandate. STORK 2.0 will be a step forward towards the creation of a fully operational framework and infrastructure for electronic identities and authentication in the EU. It does so through:

- Exploiting experiences from four cross border, cross sector pilots with real impact demonstrating the use and societal impact of the cross border, cross sector infrastructure developed

- Common specifications and building blocks for interoperable legal identities and mandates, on top of the interoperability infrastructure developed in STORK, following privacy rules (and advice from Art.29 Working Party) and enabling secure operation

- Solving within the scope of the pilots legal issues such as privacy/data protection, liability, different National regimes

- An update of the QAA model to include attributes, legal entities and mandate agreements

- eID packaged as a service for governments and businesses including a cost model and promoting the business take-up of STORK

- Addressing eID governance issues through the requirements for an accreditation body

- Investigating and promoting standardisation in the area of eID using STORK 2.0 solutions

- A knowledge repository and awareness of the STORK 2.0 infrastructure and its potential societal impact on business processes

Dalam perkembangannya di Eropa, pada tanggal 28 Agustus 2014 yang lalu, Uni Eropa telah mengubah Directive tentang Electronic Signature menjadi Regulasi tentang electronic identification and trust services. Hal tersebut dalam waktu dekat juga akan disusul adanya perubahan Directive tentang Data Protection menjadi regulasi Uni Eropa yang mengikat semua negara anggota. Selanjutnya dilakukan studi visit ke beberapa negara Eropa untuk melihat bagaimana regulasi tersebut akan diimplementasikan.

Dalam Regulasi No. 910 Tahun 2014 tersebut diatur secara jelas tentang prinsip mutual recognition, kepentingan interoperabilitas dan tanggung jawab negara dalam menjalankan electronic identification antara negara anggota dalam chapter II, yakni:

1. Article 6

2. Article 7 schemes

3. Article 8
Mutual recognition

Eligibility for notification of electronic identification

$$
\text { Assurance levels of electronic identification schemes }
$$




\section{Article 9 Notification \\ 5. Article 10 Security breach \\ 6. Article 11 Liability \\ 7. Article 12 Cooperation and interoperability}

Dalam regulasi tersebut, terdapat beberapa hal yang penting untuk dicatat, yakni:

1. Keberlakuan regulasi ini tidak berarti memaksakan semua Negara anggota untuk memiliki National e-ID card, karena hal tersebut diserahkan kembali kepada kedaulatan Negara anggota. Sistem ini hanya dimaksudkan untuk membuat apa telah yang menjadi e-ID di masing-masing Negara anggota dapat diakui dan diterima oleh Negara anggota yang lain, paling tidak untuk akses pelayanan publiknya. Standar minimum lebih ditujukan kepada layanan trust services (e-signature, e-seal, time-stamping, dst);

2. perlindungan data pribadi tetap mengikuti kaedah yang telah ditentukan dalam Directive 95/46/EC;

3. Diperkenankan penggunaan psuedonyms dalam e-transaction dimana implikasinya dikembalikan kepada sistem hokum yang berlaku pada masing-masing Negara anggota;

4. Notifikasi yang disampaikan untuk e-identification pada dasarnya adalah minimum data set, sehingga diharapkan tidak akan berbenturan dengan kebijakan yang berbeda dari masing-masing Negara anggota terhadap kategori sensitifitas data yang berlaku pada Negara tersebut;

5. Formalisasi, Syarat, dan Skema Notikasi e-identification dilakukan melalui Komisi Eropa dan penerimaannya didasarkan atas prinsip Mutual Recoginition antara Negara anggota, dimana assurance level terhadap perangkat adalah yang setara atau lebih tinggi dari Negara yang dituju;

6. Sebagai konsekwensi karena Negara yang mengajukan e-identification scheme dan e-identification means, maka Negara yang bersangkutan menjadi turut bertanggung jawab terhadap kerugian yang ditimbulkan sekiranya hal tersebut terjadi baik akibat kelalaian maupun kesengajaan. Namun bagaimana tanggungjawab hukum terhadap kerusakan/kerugian (damages) tersebut tetapa mengikuti hukum nasional masing-masing Negara yang berlaku.

Setelah melakukan wawancara langsung kepada Komisi Uni Eropa dan juga beberapa pemangku kepentingan pada beberapa Negara Eropa tersebut, pada dasarnya dapat dikatakan bahwa bagaimana imlementasi teknisnya masih belum dapat diprediksi karena terhadap Regulasi tersebut masih dibutuhkan ketentuan pelaksanaan (implementing acts) yang masih dalam proses pengerjaan. Diharapkan sesuai keberlakuannya nanti hal tersebut dapat diselesaikan dengan baik.

Jika dikaji lebih jauh, peneliti melihat bahwa implikasi dari Uni Eropa yang baru ini akan sangat signifikan terhadap standar perlindungan data pribadi, karena bukan tidak mungkin bahwa akan perubahan cara transaksi secara elektronik kedepannya nanti. Jika semula semua orang selaku konsumen harus memberikan data pribadinya untuk bertransaksi dengan pelaku usaha 
secara online dengan alasan kejelasan subyek hukum yang berkontrak, maka kedepan tampaknya tidak lagi diperlukan untuk pemberian data pribadi tersebut. Hal tersebut akan terjawab, cukup dengan merujuk kepada keberadaan identitas digital pada instansi yang berwenang. Namun tentu saja hal itu hanya dapat dilaksanakan jika sudah terdapat kepastian koneksitas dengan data public pada instansi yang bersangkutan.

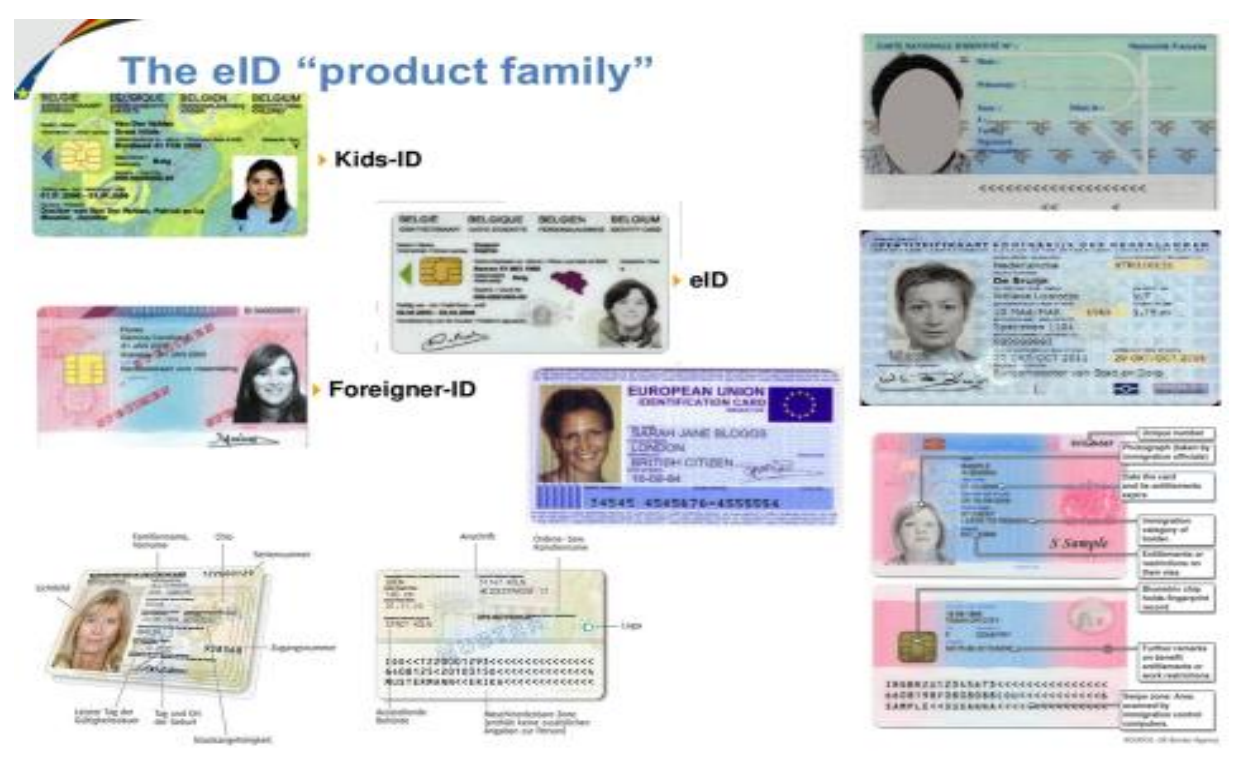

Gambar Contoh Beberapa e-ID Card.

Berdasarkan hasil visitasi ke beberapa negara Eropa tersebut dapat disampaikan sebagai berikut:

\begin{tabular}{|l|l|l|l|l|}
\hline No & $\begin{array}{l}\text { Variabel yang } \\
\text { di amati }\end{array}$ & Eropa & Indonesia & Catatan \\
\hline 1 & $\begin{array}{l}\text { Keberadaan } \\
\text { National } \\
\text { Strategy untuk } \\
\text { e-ID } \\
\text { Management }\end{array}$ & $\begin{array}{l}\text { Ada dalam Digital } \\
\text { Agenda. } \\
\text { Fungsi strategis oleh } \\
\text { Pemerintah } \\
\text { Masing2 negara } \\
\text { mengikutinya. } \\
\text { Perancis belum } \\
\text { menerapkan Citizen } \\
\text { Card }\end{array}$ & Ada & $\begin{array}{l}\text { UU Adminduk } \\
\text { dan Perpres e- } \\
\text { KTP namun } \\
\text { belum ada UU } \\
\text { tentang e- } \\
\text { Government. } \\
\text { Yang ada baru } \\
\text { terbatas Inpres } \\
3 / 2003 \text { tentang } \\
\text { eGov }\end{array}$ \\
\hline 2 & $\begin{array}{l}\text { Kebijakan } \\
\text { yang terpusat } \\
\text { dan mandatory }\end{array}$ & $\begin{array}{l}\text { Ya, namun tidak } \\
\text { sentralisasi } \\
\text { melainkan lebih } \\
\text { menganut kepada } \\
\text { desentralisasi. }\end{array}$ & $\begin{array}{l}\text { Terpusat dan } \\
\text { Mandatory, } \\
\text { kemudian } \\
\text { bergeser } \\
\text { kepada arah }\end{array}$ & $\begin{array}{l}\text { Terpusat pada } \\
\text { Kemdagri }\end{array}$ \\
\hline
\end{tabular}




\begin{tabular}{|c|c|c|c|c|}
\hline & & $\begin{array}{l}\text { Sebagian Negara } \\
\text { Lebih bersifat } \\
\text { mandatory } \\
\text { ketimbang voluntary } \\
\text { participation. } \\
\text { Pemerintah } \\
\text { membangun } \\
\text { standard identity } \\
\text { ecosystem }\end{array}$ & $\begin{array}{l}\text { desentralisasi } \\
\text { utk lebih } \\
\text { memberdayak } \\
\text { an daerah }\end{array}$ & \\
\hline 2 & $\begin{array}{l}\text { Keberadaan } \\
\text { nomor tunggal } \\
\text { identitas } \\
\text { nasional untuk } \\
\text { penduduk }\end{array}$ & $\begin{array}{l}\text { Ada, citizen services } \\
\text { number } \\
\text { Sebagian tidak } \\
\text { (Jerman). } \\
\text { Nomor kartu tetap } \\
\text { ditampilkan }\end{array}$ & $\begin{array}{l}\text { ada, Nomor } \\
\text { Induk } \\
\text { Kependuduka } \\
\mathrm{n}\end{array}$ & $\begin{array}{l}\text { Sebaiknya } \\
\text { didukung oleh } \\
\text { nomor kartu yg } \\
\text { ditampilkan }\end{array}$ \\
\hline 3 & $\begin{array}{l}\text { Keberadaan } \\
\text { sistem } \\
\text { penomoran } \\
\text { merepresentasi } \\
\text { kan tanggal } \\
\text { lahir }\end{array}$ & $\begin{array}{ll}\text { Tidak. Namun data } \\
\text { tgl } & \text { lahir } \\
\text { dicantumkan } & \end{array}$ & $\begin{array}{l}\text { Iya } \\
\text { nomor } \\
\text { mencerminka } \\
\mathrm{n} \text { tanggal, } \\
\text { bulan dan } \\
\text { tahun lahir }\end{array}$ & $\begin{array}{l}\text { pengharapan atas } \\
\text { privacy dapat } \\
\text { dikatakan rendah } \\
\text { (UU24/2013 rev } \\
\text { UU 25/2006) } \\
\text { ps84 }\end{array}$ \\
\hline 4 & Security & $\begin{array}{l}\text { ditentukan pemth } \\
\text { dan memperhatikan } \\
\text { standar regional }\end{array}$ & $\begin{array}{l}\text { ada di } \\
\text { tentukan } \\
\text { pemth dgn } \\
\text { memperhatika } \\
\text { n estándar } \\
\text { internasional }\end{array}$ & $\begin{array}{l}\text { PP-PSTE } \\
\text { merujuk kepada } \\
\text { ISO 27001/2 } \\
\text { yang diakomodir } \\
\text { dalam NSI } 27001\end{array}$ \\
\hline 5 & $\begin{array}{l}\text { Interoperabilit } \\
y\end{array}$ & $\begin{array}{l}\text { ada, mengikuti } \\
\text { ketentuan } \\
\text { Eropa }\end{array}$ & $\begin{array}{l}\text { ada, } \\
\text { ditentukan } \\
\text { oleh } \\
\text { Kemdagri, } \\
\text { namun belum } \\
\text { ada ketentuan } \\
\text { yang jelas } \\
\text { tentang PKS } \\
\text { data sharing } \\
\text { agreement }\end{array}$ & $\begin{array}{l}\text { diperlukan suatu } \\
\text { regulasi yang } \\
\text { jelas tentang } \\
\text { petukaran dan } \\
\text { tgg jwb idenity } \\
\text { intermediaries }\end{array}$ \\
\hline 6 & $\begin{array}{l}\text { User } \\
\text { Empowerment }\end{array}$ & $\begin{array}{lr}\text { ada, termasuk juga } \\
\text { dalam national } \\
\text { security } \\
\text { cybersecurity } \\
\text { awareness }\end{array}$ & $\begin{array}{l}\text { ada namun } \\
\text { tidak gencar, } \\
\text { meskipun } \\
\text { sudah desk } \\
\text { cybersecurity } \\
\text { coordinating }\end{array}$ & $\begin{array}{l}\text { sosialisasi dan } \\
\text { awareness perlu } \\
\text { lebih } \\
\text { ditingkatkan, } \\
\text { diperlukan } \\
\text { Perpres } \text { eGov dan } \\
\text { cybersecurity }\end{array}$ \\
\hline
\end{tabular}




\begin{tabular}{|l|l|l|l|l|}
\hline 7 & Kejelasan & Pemerintah & ganti rugi & sebaiknya juga \\
& tanggung & bertanggung jawab & disediakan & dibebankan \\
& jawab hukum & menyediakan trusted & pemerintah & kepada swasta \\
& penyelenggara \\
cq pemerintah & list, dst. & jika data & (pengguna dan \\
& & $\begin{array}{l}\text { pribadi } \\
\text { penduduk } \\
\text { salah dan } \\
\end{array}$ & merugikan & \\
& & ybs & \\
\hline
\end{tabular}

\section{Penutup}

\section{Kesimpulan}

Dari beberapa literatur yang diperoleh terkait suatu sistem keautentikan nasional, dapat disampaikan kesimpulan penelitian sebagai berikut:

1) Pada dasarnya, terkait identitas dgital maka terdapat dua masalah penting dalam suatu transaksi elektronik, yakni: (i) memastikan identitas para pihak, dan (ii) memastikan keamanan dan otentisitas pesan yang dikomunikasikan. Secara teknis, hal tersebut dapat diatasi dengan menggunakan Tanda Tangan Elektronik (e-signatures) yang didukung oleh Sertifikat Elektronik (e-certificate). Di Indonesia penyelenggaraan sistem keautentikan identitas subyek hukum warga negara diselenggarakan oleh Kemdagri dengan e-KTPnya sementara sistem keautentikan identitas badan hukum diselenggarakan oleh Kemkumham. Sementara keautentikan dokumen dan penyelenggaraan sistem elektronik ditentukan oleh Kominfo dan PAN.

Dalam perkembangannya, Sistem keautentikan nasional masih belum tampak terpadu karena masing-masing institusi masih belum menghamornisasikan keberadaannya, khususnya terhadap interoperabilitas antara sistem.

Sehubungan dengan itu, SIAK dan KTP-el sepatutnya menerapkan Prinsip IT Governance telah di adopsi dalam UU ITE dan PP PSTE, dalam bentuk persyaratan kehandalan dan keamanan serta kejelasan pertanggung jawaban hukum kepada setiap penduduk yang perlu dibuktikan dengan pendaftaran sistem elektroniknya serta memperoleh sertifikasi kelaikan.

a. Meskipun e-KTP dibangun berdasarkan suatu perencanaan, namun masih terjadi perdebatan tentang kehandalan, apakah teknologi yang telah dipilih sudah tepat dan sesuai dengan karakteristik kebutuhan bangsa dan Negara Indonesia. Salah satunya adalah pemilihan 
teknologi chip yang semula tertampil diluar ternyata berubah menjadi chip yang tak terlihat dan berada di dalam kartu. Hal tersebut semula dinyatakan lebih aman tetapi ternyata belakangan keluar arahan untuk tidak diperbolehkan difotocopy. Selain itu, ternyata KTP masih belum cepat tersedia dan terkirimkan dengan baik, padahal penduduk sudah melakukan pendaftaran secara fisik;

b. Meskipun biro pesonalisasi e-KTP dijalankan oleh internal Kemdagri dan juga informasi pada chip telah diamankan secara logic oleh kriptografi bekerjasama dengan lembaga terkait, namun relative masih belum dapat dikatakan terjamin keaamanannya dengan baik jika pola kerjasama pertukaran data SIAK dengan pengguna ternyata justru dibangun berdasarkan web-based. Hal tersebut memperlihatkan bahwa interoperabilitas tidak dibangun atas dasar kebutuhan permintaan yang sah dan temporal berdasarkan spesifik data melainkan lebih ditujukan kepada sharing data. Hal tersebut dapat dikatakan relative tidak aman dalam konteks privacy;

c. Meskipun terdapat ketentuan bahwa pemerintah akan melakukan ganti rugi jika terdapat kesalahan data pada eKTP, namun hal tersebut tidak tertuang secara tegas akan diemban oleh pihak-pihak yang menggunakan data tersebut. Dengan kata lain masih belum jelas bagaimana pertanggung jawaban hukum oleh pengguna dan juga pihak-pihak lain yang dapat menjadi pihak perantara dalam pemanfaatan identitas digital (Digital Identity Intermediaries).

2) Kerangka Kerja Yang Diperlukan untuk tersedianya "operating rules" ataupun "trust framework" setidaknya adalah turunan dari pasal 15 UU ITE itu sendiri yang memerlukan kejelasan koordinasi kewenangan dan fungsi kerja serta kelembagaan untuk menciptakan keterpercayaan sesuai karakteristik sector yang bersangkutan:

a. Aspek Business Process ditentukan oleh kewenangan berdasarkan UU sektoril yang bersangkutan:

i. Aspek Business Process dalam e-KTP di tentukan oleh Kemdagri;

ii. Aspek Business Process dari Administrasi Pemerintahan \& Pelayanan Publik ditentukan oleh Kementrian PAN danReformasi Birokrasi;

iii. Aspek Business Process dalam Perdagangan Melalui Sistem Elektronik ditentukan oleh Kementrian Perdagangan.

b. Aspek engineering process dan pencegahan serta pengendalian insiden di tentukan oleh Kementrian Kominfo 
sesuai UU ITE dan peraturan perundang-undangan terkait dengan pengamanan informasi (contoh; kebijakan persandian oleh Lembaga Sandi Negara);

c. Aspek Keautentikan terkait data Identitas Subyek Hukum dan penerbitan kartu, tetap memerlukantampilan nomor akta/kartu agar menjadi jelas berapa yang terpasang, berapa yang rusah dan berapa yang ditarik atau diganti karena kesalahan tampilan data pribadi pemegang KTP. Setiap eKTP yang tercetak dan juga SIAK yang mendasarinya tidak dapat terlepas dari ketentuan yang terkait dengan arsip Negara. Oleh karena itu, SIAK dan e-KTP selayaknya harus terkorelasi dengan database Sistem Infomasi Administrasi Badan Hukum (Kementrian Hukum dan HAM), Daftar Perusahaan (Kementrian Perdagangan), Aparatur Negara, dan Arsip;

d. Terkait dengan Privacy Impact Assesment, sebaiknya diterapkan pola User Centric dimana setiap pemilik data pribadi dapat melakukan pemantauan terhadap keterkinian (updating) data personal miliknya berikutotorisasi penggunaan data pribadinya oleh pihak lain (autorisasi dan autentikasi). Pengaturan tentang Sertifikasi Keandalan (trustmark) selayaknya dapat dioptimalkan keberlakuannya untuk kepastian perlindungan privacy dan data pribadi. Selain pengaturan dengan Peraturan Menteri Kominfo, hal tesebut juga dapat dikuatkan dengan kewenangan Komisi Informasi Pusat sebagai insitusi yang juga selayaknya harus dapat mengetahui batasan informasi yang dikecualikan dari Informasi Pulik yang menyangkut rahasia pribadi.

\section{Saran}

1) Kementerian Dalam Negeri harus memberikan kesempatan audit eksternal dan/atau melakukan pendaftaran dan memperoleh sertifikasi kelaikan dari Kementrian Komunikasi dan Informatika. Sekiranya ketentuan pelaksanaan tentang sertifikasi kelaikan belum ada, maka dapat diberdayakan professional indenpenden yang ada;

2) Perlu pencantuman No KTP/no kartu untuk memperjelas keautentikan;

3) Perlu penyampaian informasi publik tentang kejelasan kebijakan dan prosedur pembersihan data penduduk yang ditemukan tidak tunggal;

4) Perlu kejelasan orginalitas data dasar yang relevan dengan urusan tertentu;

5) Perlu kejelasan kebijakan dan kerangka kerja interoperabilitas sharing data berikut pemanfaatan aggregate data yang terlahir 
dari proses sharing tersebut;

6) Program $2^{\text {nd }}$ Generation KTP-el dapat menjawab kebutuhan untuk menjadi Kartu kesehatan dan pendidikan;

7) Perlu subsidi pemerintah utk perangkat reader guna dapat segera digunakan oleh semua pihak pengguna, sebagai konsekwensi penerapan yang diwajibkan;

8) Terkait keamanan informasi, maka Perpres KTP-el hrs selayaknya harus dibarengi dengan Perpres eGov dan Perpres Cybersecurity dan UU khusus terkait pengamanan informasi (Sandi);

9) Indonesia perlu mendorong ASEAN Policy untuk Kriptografi dan ASEAN e-identification and Trust Services.

\section{Rekomendasi}

1) Secara de jure pembicaraan tentang keautentikan akan mengacu kepada sistem pembuktian yang meminta adanya syarat keautentikan demi kepentingan pembuktian; Secara elektronik ke-autentikan informasi elektronik dan/atau dokumen elektronik ditentukan oleh reliabilitas dari sistem pengamanannya. Semakin tinggi tingkat keamanan maka relatif semakin tinggi nilai keautentikannya. Oleh karena itu, Negara harus segera memiliki kerangka kerja hukum yang jelas terhadap keautentikan tersebut;

2) Dalam penyelenggaraan Sistem Identitas Elektronik Penduduk Nasional (National electronic Identity Management) diperlukan sistem pengamanan yang relatif lebih tinggi yang perlu ditunjang dengan PKI Pemerintah. Sekiranya hal tersebut belum dapat dimungkinkan, harus dapat diupayakan untuk mengotimalkan sumber daya yang telah ada, satu dan lain dapat memberdayakan community $C A$ jika ada;

3) Untuk memfasilitasi dokumen public yang perlu dipertukarkan atau diakses oleh beberapa instansi terkait, maka diperlukan penyelenggaran Public Repository Document ataupun sesuatu yang menjalankan pooling penyimpanan dokumen publik yang ditunjang dengak keamanan transaksi berbasiskan tanda tangan elektronik yang didukung dengan sertifikat elektronik yang berinduk kepada PKI Pemerintah;

4) Dalam penyelenggaraan Sistem Elektronik untuk pelayanan publik, sistem keautentikan dapat terfasilitasi dengan adanya aturan tentang pendaftaran dan sertifikasi kelaikan berdasarkan PP-PSTE. Dalam perkembangan terakhir, hal ini harus disinkronkan dengan UU Administrasi Pemerintahan yang baru disahkan oleh DPR, karena setiap legalisasi dokumen terhadap dokumen elektronik berikut kemungkinan penandatanganannya secara elektronik oleh pejabat tidak akan dapat terlepas dari 
kejelasan identitas digital subyek hukum tersebut. 


\section{Daftar Pustaka}

\section{Buku}

Bajaj, Kamles K \& Debjani Nag. E-commerce: the Cutting Edge of Business, New Delhi: Tat McGraw-Hill Publishing Limited, 2000.

Barassi, Theodore S. Cybernotary: Addressing Technical Problems With OnLine Commerce, A Brave New Area Of Specialization For Lawyers, Computer Law Strategist March, 1996.

Chissick, Michael \& Alistair Kelman., Electronic Commerce Law and Practice, (2nd ed), London: Sweet W. Maxwell, 2004.

Crumlsih, Christian. The Internet Dictionary: The Essential Guide to Netspeak, California: SYBEX, 1995.

Dessemontet, François. The European Approach to E-commerce and Licensing, Brooklyn Law School, 28 January 2000.

Dumortier, Jos and Niels Vandezande. Critical observations on the proposed Regulation for Electronic Identification And Trust Services For Electronic Transactions In The Internal Market, ICRI Working Paper 06/2013., Interdisciplinary Centre for Law and ICT, K.U.Leuven.

, Caroline Goemans. "Roadmap for European Legal Research in Privacy and Identity Management., Interdisciplinary Centre for Law and ICT (ICRI)", K.U.Leuven University, Desember 2002.

Ford, Warwick and Michael S. Baum, Secure Electronic Commerce. New Jersey: Prentice Hall, 1977.

James D. Fearon. What Is Identity (As We Now Use The Word)?, Department of Political Science Stanford University Stanford, CA 94305 November 3, 1999.

Kremer, Monique. The Netherlands from National Identity to Plural Identification, transatlantic council on Migration, March 2013.

Leff, Laurence, (ed.). Notaries and Electronic Notarization, Western Illinois University. 2000.

Makarim, Edmon. Kompilasi Hukum Telematika, Jakarta: RajaGrafindo Persada, 2003.

Mann, Ronald J. \& Jane K. Winn. Electronic Commerce, New York: Aspen Law \& Business., 2003.

Mariën, Ilse \& Leo Van Audenhove, The Belgian e-ID and its complex path to implementation and innovational change, February 2010.

Mason, Stephen. Electronic Signatures in Law, London: Lexis-Nexis UK, 2003. 
Subekti. Hukum Perjanjian, Cet ke XVIII. Jakarta: Intermasa, 1998.

Prins, J.E.J., (et.al)., Trust in Electronic Commerce: The Role of Trust from Legal, an Organizational and a Technical Point of View, Netherlands: Kluwer Law International, 2002.

Peggy Valcke, Jos Dumortier., Editorial Computer, Law \& Security Review e special issue Trust in the Information Society e ICRI 20th anniversary conference - "Trust In The Information society - In Search Of Trust Generating Mechanisms For The Network Society," Interdisciplinary Centre for Law \& ICT - Interdisciplinary Institute for Broadband Technology, KU Leuven, Belgium. 2012.

Papadopouli, Maria, (ed). "European Network and Information Security Agency (ENISA)", position paper: Mobile Identity Management.

Smith, Leslie G. The Role of the Notary in Secure Electronic Commerce, Information Security, Institute Faculty of Information Technology, Queensland University of Technology, September 2006.

Stolk, Peter and Christiaan Lemmen The Netherlands, Technical Aspects of Electronics Conveyancing, 2nd FIG Regional Conference, Marrakech, Morocco, December 2-5, 2003.

\section{Peraturan Perundang-undangan dan Konvensi}

Undang-Undang tentang Informasi dan Transaksi Elektronik. UU No.11 Tahun 2008.

Undang-Undang tentang Jabatan Notaris, UU No. 30 Tahun 2004.

Undang-Undang tentang Arsip, UU No.43 Tahun 2009

Undang-Undang tentang Pelayanan Publik, UU No.25 Tahun 2009.

Undang-Undang tentang Keterbukaan Informasi Publik, UU No.14 Tahun 2008.

Undang-Undang tentang Advokat, UU No.14 Tahun 2003.

Undang-Undang tentang Perseroan Terbatas, UU No.40 Tahun 2007

Undang-Undang tentang Pasar Modal, UU No.1 Tahun 1998

Undang-Undang tentang Dokumen Perusahaan, UU No.8 Tahun 1997

Kitab Undang-Undang Hukum Perdata [Burgerlijk Wetboek] diterjemahkan oleh R. Subekti dan R. Tjitrosudibio Cet, ke xix. Jakarta: Pradnya Paramita, 1985.

UN, Hague Convention on Abolishing the Requirement of Legalization for Foreign Documents (1961).

UNCITRAL, Model Law for Electronic-commerce.

UNCITRAL, Model Law for Electronic-signatures. 
UNCITRAL, Promoting confidence in electronic commerce: legal issues on international use of electronic authentication and signature methods, 2009.

United Nations Convention for the Use of Electronic Communication for International Contract

United States of America ("USA"), the National Conference of Commissioners on Uniform State Law, Uniform Electronic Transaction Act (UETA), 1999.

USA, Uniform Computer Information Transaction Act (UCITA)

USA, E-sign for global commerce

USA, Federal Law of Evidence

EU Directive 2000/31/EC on Electronic Commerce

EU Directive 99/93/EC on Electronic Signatures

EU Directive 95/46/EC on Data Protection

EU Directive 96/9/EC on Legal Protection of Databases.

OECD (2011), Digital Identity Management: Enabling Innovation and Trust in the Internet Economy.

\section{Internet}

"eRecognition for Companies", <www.eoverheidvoorbedrijven.nl/ afsprakenstelseleherkenning/english/english.html>, diakses pada tanggal 21 September 2014.

"The Netherlands Country Profile - eID Interoperability for PEGS: Update of Country Profiles", IDABC, July 2009, <http://ec.europa.eu/idabc/ servlets/Doc?id=32286>, diakses pada tanggal 28 Juni 2014.

Presentation of DigiD, <www.digid.nl/english>, diakses pada tanggal 18 Agustus 2014.

List of public sector services using DigiD, <www.digid.nl/burger/overdigid/wie-doen-mee/>, diakses pada tanggal 23 Mei 2014.

Ministry of the Interior and Kingdom Relations, "The personal records database: for the authorities and for you. The Municipal Personal Records

Database", <www.bprbzk.nl/dsresource?objectid=19176\&type=org>, diakses pada tanggal 8 Maret 2014.

"Berger service nummer-Frequently Asked Questions", <www.burgerservicenummer.nl/veelgestelde_vragen/english_faq>, diakses pada tanggal 6 Juli 2014. 
OECD (2011), "National Strategies and Policies for Digital Identity Management in OECD Countries", OECD Digital Economy Papers, No. 177, OECD Publishing. <http://dx.doi.org/10.1787/5kgdzvn5rfs2-en>, diakses pada tanggal 6 Juli 2014.

\section{Jurnal}

Anderson, John C. \& Michael L. Closen. Document Authentication In ECommerce: The Misleading Notary Public Analog For The Digital Signature Certification Authority. John Marshall Journal Of Computer And Information Law, Spring 1999, 17 Jmarjcil 883.

Athanasopoulos-Arvanitakis, Dina \& Marilynn J. Dye. "A Proposed Code Of Professional Responsibility For Certification Authorities", John Marshall Journal Of Computer And Information Law Spring 1999., 17 Jmarjcil 1003.

Closen, Michael L. \& Thomas W. Mulcahy. "Conflicts Of Interest In Document Authentication By Attorney-Notaries In Illinois", Illinois Bar Journal June, 1999., 87 Ilbj 320.

Faerber, Charles N. "Being There: The Importance Of Physical Presence To The Notary", John Marshall Law Review, Spring 1998, 31 Jmarlr 749.

Froomkin, Michael. "The Essential Role Of Trusted Third Parties In Electronic Commerce", Oregon Law Review, Spring 1996.

Jesse, J. Richardson, Jr. "How A Sole Practitioner Uses The "Electronic Office" To Maintain A Competitive Law Practice", Drake Journal Of Agricultural Law Spring, 1998.

Lightowler, Michael. "E-commerce for Notaries in England \& Wales", Digital Evidence Journal, 2007, Volume 4 Number 1, 39 - 43.

Morel, Fraser \& Richard Jones. Demystifying Electronic Signatures And Electronic Signatures Law From An Eu Perspective, E-Commerce Law Report., July, 20024 No. 9, E-Commerce L. Rep. 4.

Sherry, Keith D. "Old Treaties Never Die, They Just Lose Their Teeth: Authentication Needs of A Global Community Demand Retirement Of The Hague Public Documents Convention", John Marshall Law Review, Spring 1998., 31 Jmarlr 1045.

Valera, Milton G. "New Technology And Global Economy Demand That American Notaries Better Prepare For The Future: Upgrading The Current Common Law System May Mean Establishing A New Class Of Cyber Professional”, John Marshall Law Review, Summer 1999., 32 JMARLR 935.

Van Alstyne, Peter J. "The Notary's Duty To Meticulously Maintain A Notary Journal", John Marshall Law Review, Spring 1998., 31 Jmarlr 777. 
Zarsky, Tal Z. \& Norberto Nuno Gomes De Andrade. "Regulating Electronic Identity Intermediaries: The "Soft eID" Conundrum", OHIO State Law Journal. 